\title{
The Gender Impact of Microfinance: The Case of Wekembe in Uganda
}

\section{Marcella Corsi, Marina De Angelis and Pierluigi Montalbano}

Microfinance industry has grown massively in the past decades. Even if it is commonly considered as an important development tool, the evidence of the socio-economic impact of microfinance is mixed, regardless of what methodology has been applied. The purpose of this study is to assess the socio-economic impact of microfinance on the clients of a microfinance program in Uganda, named Wekembe. To do so, we have conducted a survey on 294 Wekembe's clients and we have used the survey results to build a dataset, which by means of different methodologies - controlling also for selection bias by means of a generalized propensity score (GPS) matching technique - allows us to analyse the impact of microfinance on Wekembe clients' savings and women clients' empowerment.

Keywords: Microfinance, Gender, Empowerment, Savings.

JEL Classifications: J16, G21, 012.

CEB Working Paper N $13 / 045$

2013 


\title{
The Gender Impact of Microfinance: The Case of Wekembe in Uganda
}

\author{
Marcella Corsi, Marina De Angelis, Pierluigi Montalbano* \\ Sapienza University of Rome
}

\begin{abstract}
Microfinance industry has grown massively in the past decades. Even if it is commonly considered as an important development tool, the evidence of the socio-economic impact of microfinance is mixed, regardless of what methodology has been applied. The purpose of this study is to assess the socio-economic impact of microfinance on the clients of a microfinance program in Uganda, named Wekembe. To do so, we have conducted a survey on 294 Wekembe's clients and we have used the survey results to build a dataset, which by means of different methodologies - controlling also for selection bias by means of a generalized propensity score (GPS) matching technique - allows us to analyse the impact of microfinance on Wekembe clients' savings and women clients' empowerment.
\end{abstract}

Keywords: Microfinance, Gender, Empowerment, Savings

JEL codes: J16, G21, O12

* Corresponding author: marcella.corsi@uniroma1.it 


\section{Introduction}

Microcredit in the last thirty years has become an important tool to contribute to poverty alleviation and an excellent measure to improve social inclusion of the most vulnerable people and to promote self-employment and self-entrepreneurship.

Microfinance has launched a challenge to the formal financial system, which systematically excludes a large part of world's population. In fact, microcredit provides an opportunity to marginalized people by easing credit constraints on the poor and allowing them to participate in economic growth and human development.

Cross-country comparisons suggest that financial development reduces income inequalities (Clark, Xu, Zou, 2003; Bec, Levine, Loayza, 2000; Hossein, Kirkpatrick, 2002). Kai and Hamori (2009), examining the relationship between microfinance and inequality by means of a cross-country analysis of 61 countries, concludes that "microfinance plays an important role in creating a financial system endowed with the equalizing effect". However, when confronted with evidence of a positive impact, results in the literature are mixed. Among the opponents to the real impact of microfinance on development, Bateman underlines that "Institutional economics helps to clarify the issue of development through microfinance. A major claim long made of microfinance is that it can reduce the credit constraints that potential entrepreneurs often face in poor communities, and that preclude enterprise development. A contrasting viewpoint is that credit constraints affecting tiny individual enterprises are not the core problem. It is the overall lack of access to credit for small and medium enterprises that prevents microenterprises from growing into anything more substantive." 1

Several studies have recently been undertaken to estimate the impact of microfinance programs on socio-economic aspects of MFIs' clients lives, such as poverty (Banerjee et al., 2013; Immai, Arun and Annim, 2010; Cull et al., 2009), income and household purchases (Cuong at al., 2007), and women empowerment (Noreen, 2011; Asim, 2008; Corsi et al., 2006).

However, results are mixed and even finding evidence of microfinance's impact is difficult. In fact, several issues need to be solved in order to assume that the increase in the outcomes is ascribable to the microfinance treatment. The most recent impact evaluation studies are made adopting randomized control trial experiments. Choosing randomly the treated group and the control group, it is possible to control for selection bias, which means, the problem of attributing causation to a program with voluntary selection. Those who participate in microfinance programs are often wealthier and they normally have more developed entrepreneurial skills. Indeed, it is not easy to attribute their success to microfinance. Furthermore, it is very difficult to carry on these studies because of their high costs; a part from being really expensive they can be blamed to be morally not correct "randomisation may be unethical due to the denial of benefits (treatment) to otherwise eligible members, or it can be politically infeasible to provide an intervention to one group and not another." 2

In order to evaluate the impact of a microfinance institution, controlling at the same time for likely selfselection, in treatment assignment, we applied a novel impact evaluation methodology - namely a generalized propensity score matching (GPS) technique. This technique has been used to evaluate the impact of labour market programs (Kluve et al., 2012), the impact of Preferential Trade Agreements on trade flows and food security (Magrini et al., 2013a and 2013b) as well as FDIs (Du and Girma, 2009), while, in our knowledge, it has not been applied yet to the microfinance sector. In a setting with continuous treatment, GPS compares units that are similar conditional on observable characteristics and derives non-monotonic relationships and flexible dose-response functions.

We have chosen the Ugandan case study, among other developing countries experiences, because of the high potential of its economy and the stability of the country from a political and economic point of view (even if the global crisis reverted this trend in the last year). Among Sub-Saharan countries, Uganda is perceived as the one with the most vibrant and successful microfinance industry.

\footnotetext{
${ }^{1}$ Bateman (2011), p.3.

${ }^{2}$ De Silva (2012), p. 56.
} 
We have focused on Wekembe's microfinance program because it allows us to study the potential of a medium-large microfinance program (around 3,000 clients), with a long history (it was among the first institutions established in Uganda in 1999) and able to reach the poorest in the rural but also in the urban areas, without being among the biggest Ugandan MFIs.

The aim of this paper is to assess the socio-economic impact of microfinance on Wekembe' clients focusing on women clients' empowerment and the growth of clients' savings.

The paper is structured as follows. Section I provides a literature review on impact evaluation, with a focus on empowerment. Section II outlines the macroeconomic and social situation in Uganda, and section III gives an overview of the microfinance industry in Uganda. Section IV describes the MFI that we focused on. Section V presents the survey and the dataset built on the base of the survey. Section VI shows the results of the statistical analysis on the main outcomes available, such as consumption, house improving and savings. Section VII discusses the results of an indicator built to seek out women empowerment. Section VIII provides the methodologies of a broad impact evaluation on women empowerment and savings, while section IX shows the results. Finally, section X concludes.

\section{I - Literature review on impact evaluation with a focus on empowerment}

In spite of the increasing attention given by scholars to the study of microfinance impact, findings are still controversial.

Immai, Arun and Annim (2010), in their study on microfinance impact on poverty reduction in India, find a significant positive effect of microfinance on a multidimensional welfare indicator. By means of Propensity score matching and Tobit analysis, the authors are able to verify the significance of "treatment effects".

De Silva (2012), as result of a quasi-experimental evaluation in Sri-Lanka, finds positive impact on income and saving mainly in poor families, concluding that "microfinance improves household status in terms of wealth" ${ }^{3}$.

Other studies (Cuong et al. 2007; Kai and Hamori 2009) assess the impact of microfinance' programs on poverty (checking for income and household purchases) and inequality, finding a positive effect on the reduction of inequality.

In a broad study on the impact of microfinance in India, Banerjee et al. (2010), through a randomized evaluation, find that the impact differs across households. They conclude that "Microcredit therefore may not be the "miracle" that is sometimes claimed on its behalf, but it does allow households to borrow, invest and create and expand business". In a new version of their paper (2013) they find no impact in any of the development outcomes investigated by microfinance impact studies, such as profitability of businesses, consumption, education, health and women empowerment. They suggest a possible overestimation of the impacts of microfinance by the scientific literature but they also conclude that "microcredit plays its role as a financial product in an environment where access not only to credit, but also to saving opportunities, is limited. It expands bouseholds' abilities to make different inter-temporal choices, including business investment." ${ }^{5}$

Several impact studies focus mainly on women empowerment. According to the World Bank: "Empowerment is the process of increasing the capacity of individuals or groups to make choices and to transform those choices into desired actions and outcomes. Central to this process are actions that both build individual and collective assets, and improve the efficiency and fairness of the organizational and institutional context which governs the use of these assets." (World Bank empowerment website)

With regard to female empowerment, there are several motivations that have been emphasized for its pursuit. First of all, the idea that women are among the poorest and the most vulnerable of the

\footnotetext{
${ }^{3}$ De Silva (2012), p.3.

${ }^{4}$ Banerjee et al. (2010), p. 21.

${ }^{5}$ Banerjee et al. (2013), p. 34.
} 
underprivileged. Supporting them should be a priority in order to increase their standard of living and to decrease the inequalities, thus enhancing development and growth at a macroeconomic level. In fact, improving women's capabilities empowers them to make choices, which is important in it-self, but it also contributes to greater economic growth and development.

Several studies underline that an increase in women's resources results in increased well-being of the family, especially concerning children's education and health (Mayoux, 1997; Kabeer, 2001; Hulme and Mosley, 1997). Conzo and Becchetti (2010) finds that the years of credit history have a positive and significant effect on child schooling, conditional on the borrowers standard of living and distance from school.

Other scholars (Chen, 1997, Hashemi et al. 1996) find evidence for an empowerment of women trough microfinance, both from social/psychological and economic points of view. Investigating whether women's access to credit has any impact on their lives, they come to results on the economic contributions reported by women, the likelihood of an increase of asset holdings in their own names, an increase in their exercise of purchasing power, and in their political and legal awareness. They also find that access to credit is associated with higher levels of mobility, political participation, and involvement in decision making for particular credit organizations.

Seeking out for the socio-economic determinants of women empowerment, Noreen (2011) finds a positive impact of microfinance together with age, husband's education, father inherited assets, marital status and number of sons alive. The analysis is conducted on a basic indicator of empowerment measured using five sub-indicators related to child health, education, selection of spouse of children, purchase of basic goods and decision about the use of loan.

Armendariz and Morduch (2005) find that an income increase can mitigate intra-household conflicts between wife and husband.

Shuler, Hashemi and Riley (1997), and Rahman and Da Vanzo (1997) argue that microfinance increases women's opportunity cost of time plus it increases the social control, which oblige women to take care of education and health of their children.

Despite the empirical evidence on the significant impact of microfinance on women empowerment, there is no consensus among scholars whether such impact on women well-being is positive or not.

Asim (2009), by means of different methodologies - among many she also applies the Propensity score matching - finds no evidence of microfinance impact. She concludes that there is a difference between the perception of the microfinance treatment and its real impact on women empowerment.

Other studies, such as Goetz and Sen Gupta (1996), find evidence that women's participation in a credit program reinforces the still male-dominated role in the household, and the husband's power to control the loans. Rahman (1999), using an anthropological approach (interviews, participant observations, and case studies), finds that between $40 \%$ and $70 \%$ of the loans disbursed to women are used by the spouse and thus increase tensions and domestic violence within the household.

On the domestic violence and the empowerment of women decision inside their family, other studies show a positive impact (Kabeer, 2001; Hashemi, Schuler and Riley, 1999).

Mayoux (1997) finds similar evidence, supporting the claim that the impact of microfinance programs on women is not always positive. She argues that men use their wives' loans to set up their enterprises and sometimes they employ them as unpaid workers. The same author, in an empirical study on 15 microfinance programs in Africa (Mayoux, 1999), finds evidence of a need of other social development tools to be used together with microfinance in order to achieve empowerment targets, thus encouraging an integrated approach instead of a minimalistic one.

Holvoet (2005) gives more evidence to the above-mentioned conclusions, finding that in a minimalistic credit program women do not gain much in terms of decision-making patterns. On the contrary, when loans are channelled through women's groups and are combined with more investment in social 
intermediation, significant shifts in decision-making patterns are observed and this results in more bargaining and sole female decision-making.

Underling the vice-versa connection between development and women empowerment, Duflo (2011) examines whether pushing for the second one can set a vicious circle. Her conclusion is that "the interrelationships are probably too weak to be self-sustaining, and that continuous policy commitment to equality for its own sake may be needed to bring about equality between men and women." 6

Lawko, in his $\mathrm{PhD}$ thesis on microfinance impact on women's empowerment in Uganda, concludes that 'it is clear that, (i) microfinance in itself is inadequate to improve clients' well-being unsupported by other poverty reduction policy interventions; yet, (ii) regardless of the marginal net gain households achieved, microfinance significantly facilitated women's empowerment, individually and collectively." 7

Beyond the opposing views on the impact of microfinance programs, we find a third view in the literature, which stands as a middle ground between what we have discussed above. Cheston and Kuhn (2002) underline that, even if not directly connected with the empowerment, microfinance program's participation contributes to women's ability to challenge social injustices and a discriminatory system. By helping women to meet their practical needs and to increase their efficacy in their traditional roles, microfinance can help women to gain respect and achieve more in their roles, which can lead to increased esteem and self-confidence. Mayoux (2006) concludes that "firstly, microfinance practices do not always produce automatic empowerment benefits for women; therefore, empowerment must be strategically planned for in MFIs. Secondly, empowerment approaches allow microfinance institutions to realize their full potential in contributing to a number of critical dimensions of women's empowerment. Finally, empowerment approaches are often compatible with other approaches to microfinance (e.g. financial sustainability), and can actually enbance the aims of these other approaches in many cases." 8

\section{II - Country Overview}

Uganda is a resource-based economy, located in the heart of the Great Lakes region. In 2011, the economy experienced a slowdown but this trend is expected to improve in 2012 and 2013, mainly driven by the growth of the oil sector (see Table 1). The economy was performing well before the global crisis, around 7\% per year, and Uganda's per capita income has increased consistently: from 2003 to 2011 its value has more than doubled (from USD 237 in 2003 to USD 487 in 2011); per capita income at purchasing power parity of USD was 1,354 in 2011. Youth unemployment (age of 15-24 labour force) was estimated at 5.9\% in 2009 and total unemployment was $4.2 \%$. According to the National Bureau of Statistics, in 2009-2010 79\% of the working population were self-employed while around $20 \%$ where employees. In spite of the stability of the country in the last years, inflation is forecasted to drop in 2013, due to global falls in food and fuel prices and the impact of a monetary contraction by the Bank of Uganda.

Table 1 - Macroeconomic indicators

\begin{tabular}{|l|l|l|l|l|}
\hline & $\mathbf{2 0 1 0}$ & $\mathbf{2 0 1 1}(\mathbf{e})$ & $\mathbf{2 0 1 2}(\mathbf{p})$ & $\mathbf{2 0 1 3}(\mathbf{p})$ \\
\hline Real GDP growth rate & 6.1 & 4.1 & 4.5 & 4.9 \\
\hline CPI Inflation & 4.1 & 18.8 & 16.0 & 14.1 \\
\hline GDP per capita growth rate & 5.2 & 3.8 & 2.6 & 3.3 \\
\hline
\end{tabular}

Source: OECD (2012), African Economic Outlook. ${ }^{9}$ Notes: estimates (e) and projections (p) based on authors' calculations. Figures for budget balance refer to fiscal year July (n-1) / June (n).

\footnotetext{
${ }^{6}$ Duflo (2011), p.1051.

${ }^{7}$ Lawko (2006), p.190.

8 Vani (2011), p.13.

${ }^{9}$ Data from national authorities.
} 
Agriculture is the most important sector and it contributes nearly one-quarter of the country's GDP, employing over $2 / 3$ of the working force on small enterprises. The major cash crops are coffee (main source of foreign trade), tea and tobacco. In addition, the country holds substantial natural resources like fertile soils, regular rainfalls, small deposits of copper, gold, and recently discovered oil.

Micro-enterprises represent the main part of the Ugandan economy, employing a third of the workingage population. ${ }^{10}$

Uganda's population is approximately 34.5 million, growing at 3\% per year, with only $13.5 \%$ living in the urban areas. It has one of the youngest populations of Africa: only $2 \%$ of the population is above 65 years, a half is between 15 and 65 years, and $48 \%$ is below 14 years old. The demographic structure poses a big challenge in terms of employment of young people and among the main reasons for the youth unemployment in Uganda we find the lack of employable skills and limited access to financial and technical resources.

During the 1990s life expectancy had been declining in Uganda due to the HIV/AIDS pandemic disease and in 1999 the average life expectancy was 42 years. Nowadays, it is 54 years. The Ugandan population of orphaned children due to the HIV is approximately 1.5 million. The Infant mortality rate on 1000 children is $74 .{ }^{11}$

The Human Development Index trend over the last years underlines the slow development of the country, which is still 161st on a rank of 187 countries and below the Sub-Saharan Africa average (0.463).

Table 2 - Uganda Human Development Index

\begin{tabular}{|l|l|l|}
\hline Years & Index Value & Ranking \\
\hline 2000 & 0,409 & $158(174$ countries $)$ \\
\hline 2005 & 0,508 & $144(177$ countries $)$ \\
\hline 2010 & 0,422 & $143(169$ countries $)$ \\
\hline 2011 & 0,446 & $161(187$ countries $)$ \\
\hline
\end{tabular}

Source: UNDP Data

Despite of the high GDP growth rates recorded in recent years, a big share of the population still lives in poverty. However, the share of the population below the poverty line has constantly decreased, from $56 \%$ in $1992-93$ to $31 \%$ in $2005-06$. Nowadays it is $24 \%$ (29\% in the rural areas and $9 \%$ in the urban ones). The share of people earning less than USD 1.25 per day is $38 \%$ and the share of people earning less than USD 2 is $68 \%$. According to the poverty gap indicator (see Table 3), the distance from the poverty line has severely decreased in the last years, which indicates an improvement in monetary welfare.

While the poverty has decreased, the inequalities have been slightly increasing. The Gini Index increased from 0.37 in $1992-93$ to 0.42 in 2009 . The $20 \%$ of people with the highest revenue own $50.5 \%$ of country income, while the $20 \%$ lowest household incomes own only the $5.8 \% .{ }^{12}$ Despite of the really low development achieved in the country, the gender gap is one of the lowest in the developing world: the country ranks 28 th out of 135 countries with an Index of 0.723 . Figure 1 shows the gender gap sub indexes. Table 3 summarises the Millennium Development Goals' country achievements.

\footnotetext{
${ }^{10}$ Ugandan Bureau of Statistics (2012) Statistical Abstract.

${ }^{11}$ See OECD (2012), African Economic Outlook; United Nations (YEAR), World Population Prospects - The 2010 Revision, Department of Economic and Social Affairs, Population Division.

12 World Bank Data, Countries Indicators.
} 
Fig. 1 - Gender gap sub indexes

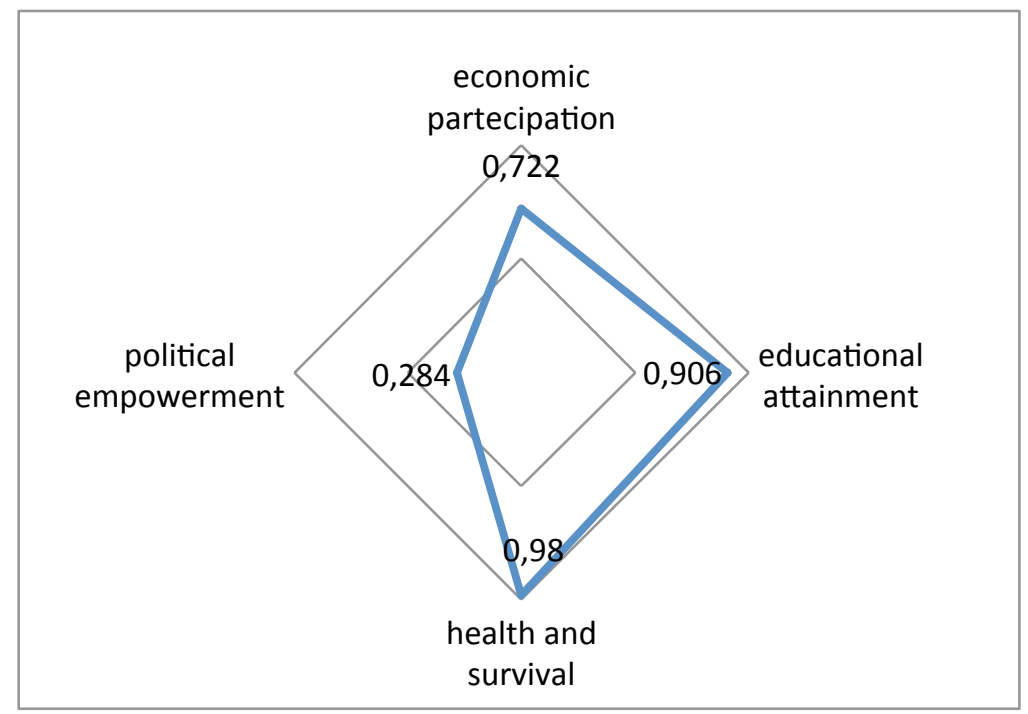

Source: World Economic Forum (2012), The Global Gender Gap Report.

Table 3 - Uganda Millennium Development Goals achievements

\begin{tabular}{|c|c|c|c|}
\hline MDG & Indicator & Baseline & Current status \\
\hline $\begin{array}{l}\text { 1: Eradicate extreme } \\
\text { poverty and hunger }\end{array}$ & $\begin{array}{l}\text { 1.1 Proportion of population below national } \\
\text { poverty line } \\
\text { 1.2 Poverty gap } \\
\text { 1.3 Prevalence of underweight children under } \\
\text { five years of age }\end{array}$ & $\begin{array}{l}56 \%(1992 / 3) \\
21(1992 / 3) \\
26 \%(1995)\end{array}$ & $\begin{array}{l}23 \%(2009 / 10) \\
9(2005 / 6) \\
16 \%(2005 / 6)\end{array}$ \\
\hline $\begin{array}{l}\text { 2: Achieve universal } \\
\text { primary education }\end{array}$ & $\begin{array}{l}\text { 2.1 Net enrolment ratio in primary education } \\
\text { 2.2 Primary completion rate } \\
\text { 2.3 Literacy rate of } 15-24 \text { year-olds }\end{array}$ & $\begin{array}{l}\text { (all } 2000 \text { ) } 86 \% \\
\text { boys: } 89 \% \\
\text { girls: } 82 \% \\
\text { (all } 2001 \text { ) } 63 \% \\
\text { boys: } \mathrm{n} / \mathrm{a} \\
\text { girls: } \mathrm{n} / \mathrm{a} \\
81 \%(2002 / 3) \\
\end{array}$ & $\begin{array}{l}\text { (all } 2009 \text { ) } 93 \% \\
\text { boys: } 96 \% \\
\text { girls: } 90 \% \\
\text { (all } 2009 \text { ) } 52 \% \\
\text { boys: } 55 \% \\
\text { girls: } 48 \% \\
88 \%(2008)\end{array}$ \\
\hline $\begin{array}{l}\text { 3: Promote gender } \\
\text { equality and empower } \\
\text { women }\end{array}$ & $\begin{array}{l}\text { 3.1 Ratios of girls to boys in } \\
\text { primary/secondary/tertiary education } \\
\text { 3.3 Proportion of seats held by women in } \\
\text { national parliament }\end{array}$ & $\begin{array}{l}\text { (all 2000) } \\
0.93 / 0.79 / 0.58 \\
18 \%(2000)\end{array}$ & $\begin{array}{l}(\text { all 2009) } \\
1.00 / 0.84 / 0.79 \\
30 \%(2006)\end{array}$ \\
\hline $\begin{array}{l}\text { 4: Reduce child } \\
\text { mortality }\end{array}$ & $\begin{array}{l}\text { 4.1 Under-five mortality rate (per 1,000 live } \\
\text { births) } \\
\text { 4.2 Infant mortality rate (per 1,000 live births) } \\
\text { 4.3 Proportion of } 1 \text { year-old children } \\
\text { immunized against measles }\end{array}$ & $\begin{array}{l}156(1995) \\
81(1995) \\
82 \%\end{array}$ & $\begin{array}{l}137(2005 / 6) \\
76(2005 / 6) \\
81 \%(2009)\end{array}$ \\
\hline $\begin{array}{l}\text { 5: Improve maternal } \\
\text { Health }\end{array}$ & $\begin{array}{l}5.1 \text { Maternal mortality ratio (per 100,000 } \\
\text { births) } \\
5.2 \text { Proportion of births attended by skilled } \\
\text { health personnel }\end{array}$ & $\begin{array}{l}506(1995) \\
38 \%(1995)\end{array}$ & $\begin{array}{l}435(2005 / 6) \\
42 \%(2005 / 6)\end{array}$ \\
\hline
\end{tabular}




\begin{tabular}{|c|c|c|c|}
\hline & 5.3 Unmet need for family planning & $29 \%$ & $41 \%$ \\
\hline $\begin{array}{l}\text { 6: Combat } \\
\text { HIV/AIDS, malaria } \\
\text { and } \\
\text { other diseases }\end{array}$ & $\begin{array}{l}\text { 6.1 Condom use at last high-risk sex, } \\
\text { female/male } \\
\text { 6.2 Proportion of population with advanced } \\
\text { HIV infection with access to antiretroviral } \\
\text { Drugs } \\
\text { 6.3 Proportion of children under } 5 \text { sleeping } \\
\text { under insecticide-treated bed nets } \\
\text { 6.4 Prevalence rates associated with } \\
\text { tuberculosis }\end{array}$ & $\begin{array}{l}39 \% / 61 \%(2000 / 1) \\
44 \%(2008) \\
8 \%(2003) \\
652(2003)\end{array}$ & $\begin{array}{l}35 \% / 57 \%(2005 / 6) \\
54 \%(2009) \\
50 \%(2010) \\
350(2008)\end{array}$ \\
\hline $\begin{array}{l}\text { 7: Ensure } \\
\text { environmental } \\
\text { sustainability }\end{array}$ & $\begin{array}{l}\text { 7.1 Proportion of population using an } \\
\text { improved drinking water source, urban/rural } \\
\text { 7.2 Proportion of population using an } \\
\text { Improved sanitation facility, urban/rural }\end{array}$ & $\begin{array}{l}87 \% / 51 \% \\
(1999 / 2000) \\
\text { n/a }\end{array}$ & $\begin{array}{l}87 \% / 64 \%(2005 / 6) \\
74 \% / 62 \%(2007 / 8)\end{array}$ \\
\hline $\begin{array}{l}\text { 8: Develop a global } \\
\text { partnership for } \\
\text { development }\end{array}$ & $\begin{array}{l}\text { 8.1 ODA to GDP ratio } \\
\text { 8.2 Stock-outs of tracer drugs } \\
\text { 8.3 Cellular subscribers per } 100 \text { population }\end{array}$ & $\begin{array}{l}8.6 \%(2005 / 6) \\
67 \%(2002 / 3) \\
4.5(2004)\end{array}$ & $\begin{array}{l}5.2 \%(2009 / 10) \\
65 \%(2006 / 7) \\
28.9(2008)\end{array}$ \\
\hline
\end{tabular}

Source: MOFPED (2010). ${ }^{13}$

\section{III - Financial sector and microfinance industry in Uganda}

According to Schumpeter (1911) and Levine and King (1993), high levels of financial development are positively correlated with economic development while, on the contrary, low income countries still face financial exclusion realities. Development and financial inclusions are strictly related, as well as inequalities and financial inclusion. Batbekh and Blackburn (2008) integrates microfinance into a dynamic macroeconomic model of income distribution, showing a decrease in poverty and inequalities while microfinance is introduced in the model. Moreover, Claessens and Perotti (2005) emphasizes how, in order to reduce inequality, financial systems have to became not just deeper, but also broader, trying to reach people excluded. Due to the low development achievements and financial exclusion problem, Sub-Saharan Africa is a perfect object of study in the analysis of the ability of microfinance in enhancing development and achieving poverty outreach.

The African Economic Outlook, published by the OCDE in 2012, underlines the central role of financial exclusion among the difficulties faced by formal and informal firms in Africa (see figures 2 and 3). According to it, the second obstacle faced by formal firms is financial exclusion, ranking after the lack of energy supply. However, for the informal firms, financial exclusion ranks as the first and most important obstacle.

\footnotetext{
${ }^{13}$ Quoted in Matovu, Twimukye, Musisi and Levine (2011), p. 5
} 




Source: OECD (2012), African Economic Outlook.

Fig. 3 - Chief obstacles faced by informal firms

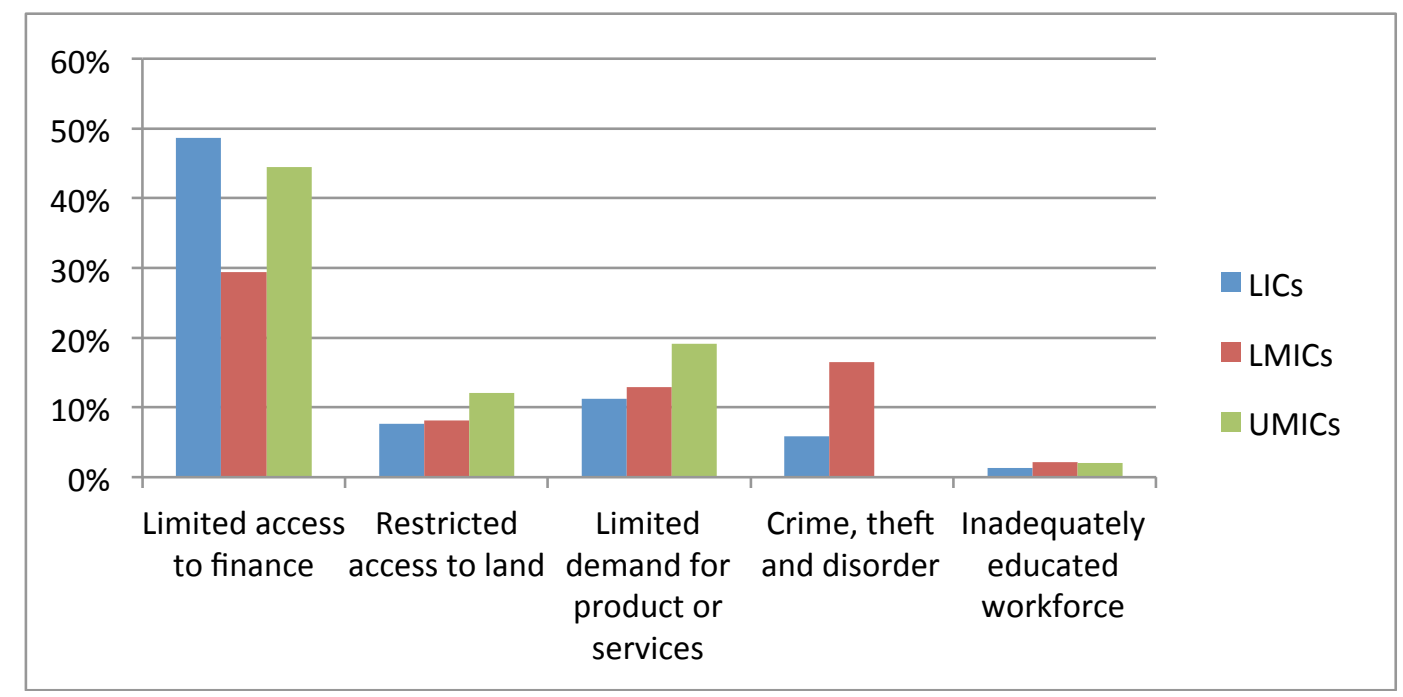

Source: OECD (2012), African Economic Outlook.

The history and development of the financial sector in Uganda is strictly connected with the political history of the country. In fact, after the independence achieved in 1961, the government founded the first domestic bank, i.e. the Uganda Commercial Bank (UCB), to broaden access to financial services for Ugandans. Despite of this first effort, Uganda's formal financial system has been long considered to be one of the least developed in Sub-Saharan Africa, being underdeveloped and offering only a very limited number of financial products for business entrepreneurs. In order to overcome some of these issues, the Government set up a Financial Sector Reform Program in 1993, which showed some positive results. However, the formal financial system continued to be extremely fragile and experienced a serious crisis between 1997 and 1999, when five banks, including the popular Cooperative Bank, unexpectedly closed because of internal financial problems. Moreover, the partial privatization of Uganda Commercial Bank resulted in the closing of many rural branches, leaving some areas of the country with no formal financial services. One of the main reasons of what happened to Ugandans banks is related to the lacking of a supervising and regulating role by the bank of Uganda (BoU) (AMFIU, 2008). 
The financial sector in Uganda was restructured again in 2002, when the BoU ordered the restructuring of Post Bank. Then, in 2004 the Financial Institutions Act replaced the Banking Act and focused on safety of all credit institutions as well as the systemic reliability of the whole financial sector.

Despite growth in the formal banking system, financial access remained limited. "By 2004, tier 1 to 3 financial institutions were in 51 of the 55 districts in the country, serving about 87 thousand people per bank branch. The banking sector grew rapidly between 2006 and 2010, with assets nearly doubling to 28 percent of GDP." ${ }^{14}$ This did not turn into enhanced financial services outreach, and the lower penetration of the formal financial sector into the rural areas allowed for the emergence of other players, including informal financial institutions and, in particular, microfinance institutions.

Among Sub-Saharan countries, Uganda shows one of the most vibrant and successful microfinance sector in Africa. In fact, some microfinance institutions have experienced strong growth and nowadays have a considerable number of clients; for example three of them - that is Brac-Uganda, Equity Uganda and Finca-Uganda - serve more than 50.000 clients each. ${ }^{15}$

The Microfinance Deposit-taking Institutions Act of 2003 put under the BoU supervision all non-memberbased microfinance institutions, which wanted to legally collect and intermediate savings. So microfinance became integrated in the regulated financial system from a completely informal and unregulated scenario.

Currently, the Ugandan financial system is divided into three broad categories:

- "Formal financial institutions: Banks, Credit Institutions and Microfinance Deposit taking Institutions (MDIs). These are supervised by BoU under the Financial Institutions Act 2004 and the MDI Act 2003

- Semi-formal financial institutions with some form of legal status, but that are not supervised by BoU. These include SACCOs registered under the Cooperative Societies Statute 1991, MFIs registered under the Companies Act and microfinance NGOs registered under the non-governmental organizations (NGO) Statute

- Informal setups: All other member-based associations, including village savings and loans associations (VSLAs), accumulated savings and credit associations (ASCA) and rotating savings and credit associations (ROSCAs)." 16

The microfinance industry in Uganda was born to fill a gap of the financial market, which left people living in rural areas and other low-income people lacking financial services. Informal financial arrangements like ROSCAs have existed in many forms in Uganda for several decades but, from the mid 80s, also microcredit programs started emerging as side components of social welfare programs. Given the macroeconomic stability, the microfinance industry in Uganda had favourable environmental conditions to grow up and, furthermore, the industry was able to overcome some of the vicious consequences of former instability and bad practices of the financial system.

Anyway, even if none of the bigger MFIs has until now faced serious delinquency problems, it is suitable to take the industry under tight control: in fact, the massive increase of the sector in recent years, if not correctly addressed by both MFIs and public institutions, could lead multi borrowing troubles as it has happened in other countries in 2009-2010 (Andhra Pradesh, Bosnia-Herzegovina, Nicaragua, Morocco).

Ugandan microfinance industry has grown substantially, reaching 3.5 million of clients in 2012, from 300,000 reached 20 years ago (AMFIU, 2008), and nowadays, new providers continue to enter the market, many of them working mainly in Kampala and the surrounding region. Given to this impressive growth, some providers fear that some urban areas in these parts of the country may already be close to saturation. However, the literature (Wright and Ripper, 2003) underlines the good effect of the competition on the microfinance industry in Uganda.

\footnotetext{
14 IMF (2012), p. 23.

${ }^{15}$ Data MIX Market Country profile Uganda.

16 AMFIU (2008), p. 13.
} 
In what follows we provide some data and information regarding the characteristics of Ugandan microfinance clients. Generally speaking, even if they are not among the poorest, though they are clearly not wealthy. In fact, they have access to the basic needs, they spend a high proportion of their earnings on food and education of children, they remain vulnerable to shocks, and access to microfinance has proven to play an important role in managing this vulnerability (Wright et al., 1999a). Those significantly below the poverty line do not seem to join Ugandan MFIs, or at least not the biggest ones.

Fig. 4 - Uganda's Financial Access



Source: Synovate (2010), FinScope II, 2009 findings.

According to the FinScope 2009 and 2007, financial access in Uganda may be presented as shown in the figures 4 and 5 . According to these data, only $15 \%$ of the people in rural areas are formally banked and the informal sector serves more rural then urban people, which makes the microfinance ability of reaching the rural areas essential. The clients (both formal and informal) demands mainly saving, then credit products, transactions and very few of them demand insurance products (Fig. 7).

Fig. 5 - Uganda’s Financial Access by location



Source: Synovate, 2010, FinScope II 2009 Findings 
Other data ${ }^{17}$ show that financial exclusion was even deeper in 2007 , and when informal services are not considered, the proportion of financial excluded increases to $62 \%$

Fig. 6 - Uganda's Financial Access (2007)

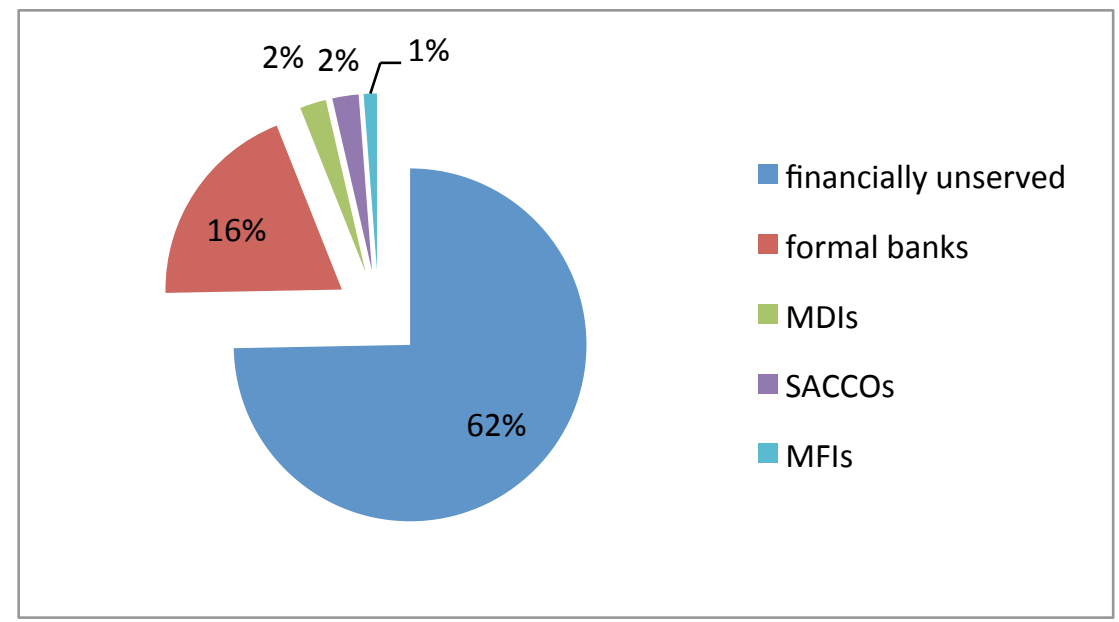

Source: Synovate (2010), FinScope II, 2007 findings.

Fig. 7 - Financial landscape formal access



Source: Synovate (2010), FinScope II, 2009 findings.

\section{IV - Wekembe Microcredit Scheme}

Wekembe has a long history and it is among the first MFIs set up in Uganda. The Bishop of the Luwero catholic diocese established it in 1998, following the request of a group of women living in the rural surroundings of Kampala who didn't have access to financial services. Wekembe is a LTD and the bank behind the program is the Centenary Bank, the main microfinance funder in Uganda. Its name means to "work hard to pull out of a certain condition": its primary goal was at the beginning to provide access to financial services to active poor women, aiming at enabling them to improve their 
households' quality of life. Wekembe's original mission was to strengthen the role of women in society because Wekembe officers thought that lending to women would have benefit the whole family and, in addition to that, they considered that women have proven to be better payers.

Nowadays, the mission of Wekembe has become wider, and it focuses on poverty outreach, regardless of the gender issue. During the past ten years Wekembe has been addressing his services not only to women and currently its clients are 70\% women and 30\% men. It uses the group lending methodology, which has combined several elements of the Grameen/Village banking methodology. Wekembe's clients are currently 3,000, organized in around 250 groups: members are organized in groups of 5-7 people based on a criteria of 5 likeminded individuals, those that trust each other, all female/male, those that leave in close proximity and not relatives. These small solidarity groups cluster to form a Village bank, which is a community managed association with a leadership structure. Members are trained for a minimum of 7 days in the rules and procedures of the credit scheme, leadership, group dynamics, importance of savings, how to appraise their businesses, record keeping etc. Afterward, the supervisor conducts an oral test and the successful members can access a loan after the loans officers have evaluated them. The credit officers, who train the clients, conduct field visits and mentor the clients or give them business advice. It is basically a constant relationship, which does not end after the loan disbursement.

Loan amounts range from 5,000 Uganda shillings to 3,000,000 Uganda shillings. Wekembe carries an interest rate of $15 \%$ for a period of 6 months. The average loan for client ranges from around 400,000 shillings for the first loan to 800,000 for the fourth and fifth loan. Wekembe's staff periodically visits the clients to facilitate the weekly/monthly group meetings and to make the recoveries. Members manage their own affairs, they open a group account for their savings, register at the sub county level as a community development association and they keep their records as well as take critical decisions affecting their group and of course they learn from each other.

Wekembe's integrated approach ${ }^{18}$ has helped its members to improve their economic and social conditions instilling a new culture of saving and access to credit among its members.

The director of Wekembe is a woman, which makes the institution a particular case study in the country because of the prevalence of MFIs with unbalanced governance towards men management. Wekembe's management committee is made of 3 members, including the loan officers' supervisor and 11 loan officers ( 6 women and 5 men). The rate of rural to urban clients is about 3 over 4 , which is one of the main reasons why we have chosen to work on this program, in fact most of the big MFIs in Uganda are concentrated in the urban area. Wekembe works mainly in five districts: Kampala, Mpigi, Wakiso, Luweero, and Mukono with few clients in the two districts of Nakaseke and Nakasongola.

\section{V - Survey and dataset construction}

The survey we have conducted is an adapted version of that conducted by Corsi et al. (2006) in 12 Mediterranean countries in $2005 .{ }^{19}$ We have changed some questions to adapt the questionnaires to the Ugandan reality (the questionnaire is presented in Annex 1).

One of the main adjustments concerned the question B2, which was originally made to check the amount disbursed to the client: we added the questions: "How much did you applied for?" in order to check any kind of discrimination between man and woman clients. We then have added the option trade to the question B5 "What did you use your loan for" because we wanted to check whether

\footnotetext{
${ }^{18}$ Integrated oriented microfinance program offer to the entrepreneurs development services such as business and production training, social services, marketing analysis, health, nutrition and education training, etc. Minimalistic program just provide credits.

${ }_{19}$ The countries under study where: Albania, Bosnia, Croatia, Egypt, France, Italy, Jordan, Kosovo, Lebanon, Morocco, Spain and Tunisia.
} 
microfinance can help the entrepreneurs not only to get out from the poverty, but also to contribute to the economic growth of the country.

We have realized two field missions in order to verify the on-going surveying process. We went to Kampala when the credit officers had just started the interviews and we organized a focus group in order to check whether the questionnaires were appropriate and if the clients were able to understand them properly. Wekembe's staff showed the interest for their job, which represent for most of them more than a simple profession - some of the loan officers are also volunteer in organizations involved in training course for financial and social excluded people.

We also conducted twenty interviews face to face to check whether the answers given by the clients to the credit officers would have been sincere.

The sample size has been calculated applying De Luca (1990) sample size formula. ${ }^{20}$

$$
n=\frac{z_{\alpha / 2}^{2} * N}{4(N-1) \Delta^{2}+z_{\alpha / 2}^{2}} 21
$$

The results of the De Luca's formula is that with a minimum sample of 93 observations we can be sure at $95 \%$ that the answers of our interviewed will vary of $10 \%$ (more or less) by the real answer. With 341 observations we can be sure at the $95 \%$ that the answer of our interviewed will vary of $5 \%$ (more or less) by the real answer

Once the minimum size of the sample has been fixed we implemented a stratified sampling, ${ }^{22}$ in order to recreate the real population representing the share of men and women, of rural and urban clients, of clients per districts and the percentage of clients per credit officers.

Thanks to the credit officers' professional work, we have been able to build a dataset of 111 variables per 294 observations.

\section{VI - Statistical findings}

In the following section, we show the results of the statistical analysis of the dataset.

\section{Main characteristics of clients}

Gender distribution in the sample is representative of the population $70 \%$ of female, $30 \%$ male. The female credit officers (6 out of 11) made $53 \%$ of the interviews.

Wekembe's clients are in average young (around 35 years old), even if there are many clients between 55 and 64 years old and several older than 65 . Male borrowers are, in average, younger then the female ones.

\footnotetext{
${ }^{20}$ De Luca A. (1990).

${ }^{21}$ Where $\mathrm{z}_{\alpha / 2}=$ value for selected alpha level of .025 in each tail $=1.96$ (the alpha level of .05 indicates the level of risk the researcher is willing to take that true margin of error may exceed the acceptable margin of error). Where $\Delta=z_{\alpha}+\sqrt{\operatorname{var}(p)}=$ 0.05 .

22 "Stratified sampling is a probability sampling procedure in which the target population is first separated into mutually exclusive, homogeneous segments (strata), and then a simple random sample is selected from each segment (stratum). The samples selected from the various strata are then combined into a single sample. This sampling procedure is sometimes referred to as quota random sampling." Daniel (2012), p. 171.
} 
Fig. 8 - Borrowers and Credit Officer Sex
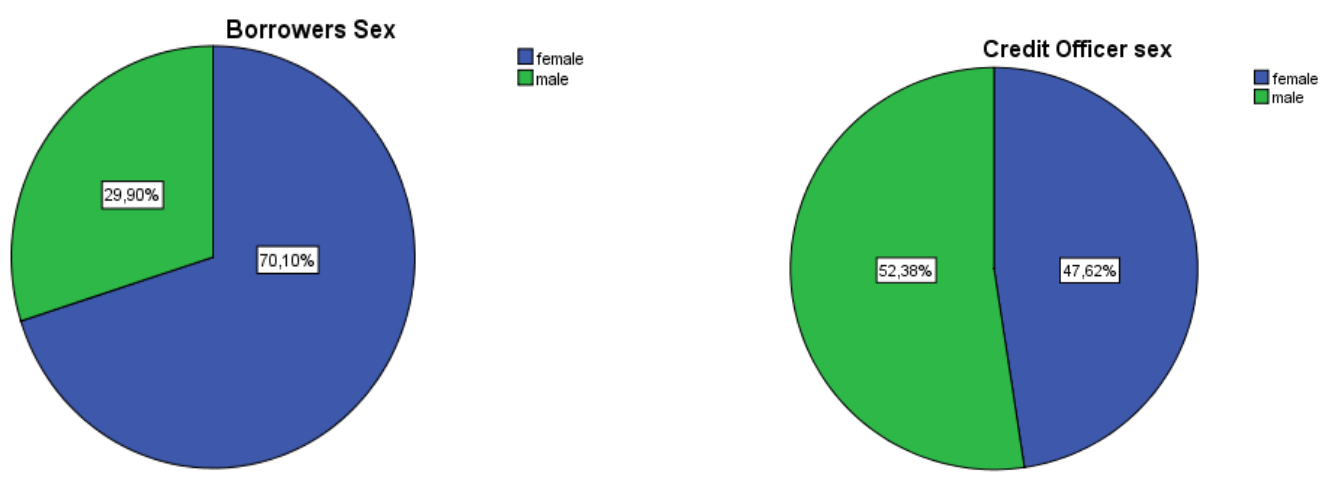

Source: Elaborations on survey data.

Fig. 9 - Borrower's age

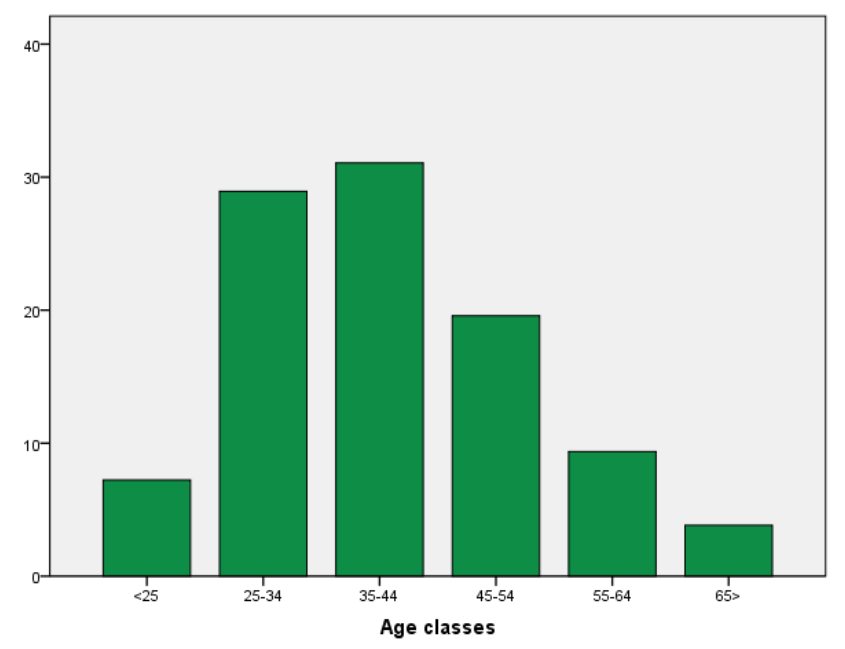

Source: Elaborations on survey data.

Fig. 10 - Clients' civil status



Source: Elaborations on survey data. 
Less than a half of women clients are married, while $67 \%$ of male is married. The literacy rate is more or less the same between males and females, while average years of school is higher for males (Table 4).

Table 4 - Literacy rate

\begin{tabular}{|l|l|}
\hline & Value \\
\hline Literacy clients & $88 \%$ \\
\hline Literacy partners & $95 \%$ \\
\hline Average years of school attended clients & $11(10 \mathrm{~F} / 13 \mathrm{M})$ \\
\hline Average years of school attended partners & 12 \\
\hline
\end{tabular}

Source: Elaborations on survey data.

Most of the clients are self-employed (70\%), 15\% are salaried, and the remaining part is distributed among unemployed, students or housewives, without gender differences. The field of work of clients, graphically presented in Figure 11, shows that women are more concentrated in the agricultural sector (around $40 \%$ of them are involved in farming activities), whereas men are more concentrated in the commerce and service fields (40\%).

Fig. 11 - Clients field of work

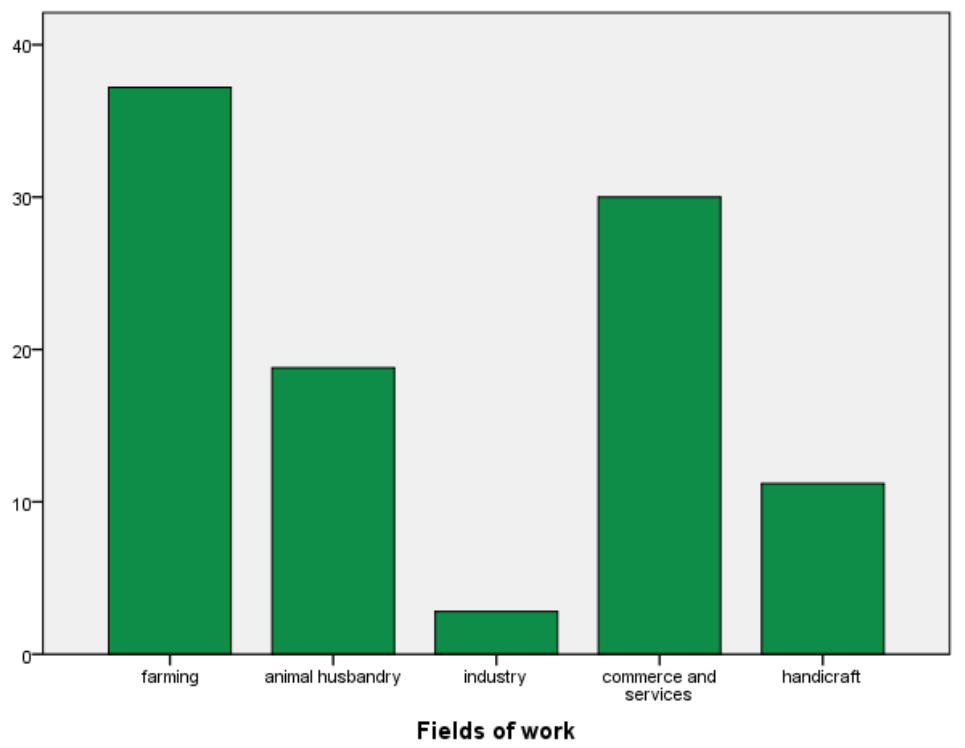

Source: Elaborations on survey data.

\section{Income and outreach measures}

The median monthly income of Wekembe's clients is 250,000 shillings (USD 98). The average income is 330,000 (USD 129), 280,000 for women and 415,000 for men. The gender gap among income in Wekembe's clients is pretty high: women's average income is $67 \%$ of the average men's income. According to the Uganda 2009/2010 National Panel Survey Data the average income per month in Uganda is equal to 1,1 million Ugandan shillings, meaning that the entire sample is below the national average income. ${ }^{23}$

${ }^{23}$ Micro data from a survey conducted in Uganda in 2009/2013 on 13,000 households. Available at the World Bank's website. 
Around 35\% of the clients of our sample live with less than USD 2 per day (165,000 shillings per month). ${ }^{24}$ According to the Income gap ratio, ${ }^{25}$ we have found that the average income of the poorest client of Wekembe is $78 \%$ far from the poverty line.

From an outreach point of view Wekembe can be defined as a high performing program compared to Ugandan microfinance sector.

\section{Credit}

Almost every client asked for a six months loan. Table 5 shows that women apply for lower loans than men and this happens until the request of the second loan, while for the third and forth loans they ask more than men, maybe because they become more self-confident about their activities. Comparing the amount applied for with the income earned per month, we find a riskier attitude of women compared to men, as the formers apply for loans similar to men, despite the fact that their incomes are half of those of men. An important indicator of gender discrimination is the amount disbursed compared to the amount applied. In our sample, we find that loans are smaller when men are applying compared to women. This finding requires a deeper investigation, which includes controlling for other variable. Furthermore, this result, if confirmed by the econometric analysis, may be in contrast to other evidences in the literature (Agier and Szafarz, 2010 and 2011; Alesina et al. 2012), which assess that despite of the nature of microfinance as a tool to improve women's exclusion from finance, there is a discriminatory attitude of the credit officers against women.

Table 5 - Loans amount (applied for/disbursed)

\begin{tabular}{|l|l|l|l|l|}
\hline & \multicolumn{2}{|l|}{ Amount applied } & \multicolumn{2}{l|}{ Amount disbursed } \\
\cline { 2 - 5 } & Male & Female & Male & Female \\
\hline I Loan & 430,000 & 365,000 & 398,000 & 349,000 \\
\hline II Loan & 568,000 & 539,000 & 543,000 & 519,000 \\
\hline III Loan & 659,000 & 713,000 & 607,000 & 694,000 \\
\hline IV Loan & 817,000 & 827,000 & 739,000 & 801,000 \\
\hline V Loan & 720,000 & 711,000 & 680,000 & 620,000 \\
\hline
\end{tabular}

Source: Elaborations on survey data.

The analysis of the difficulties in reimbursement shows that $35 \%$ of clients had troubles in reimbursing their loans. Figure 12 shows the main difficulties declared by respondents - please note that many clients who have chosen the option "others" clarify that the reason was the default of others member of their own group.

When we check the use of the loan we found a result common in microfinance: $70 \%$ of clients asked a loan in order to improve an existing activity, 10\% of them used it to start a new one, $9 \%$ to re-enter in the labour market and 5\% of them use the loan for trade activities. We asked them to select two answers about the main use of the loan: the second option was "trade activities" for $28 \%$ of them. This result is interesting from an economy growth point of view: in fact, further research could address the study, on the one hand, of the likelihood of microfinance programs in helping the clients to develop

\footnotetext{
${ }^{24}$ Headcount ratio: $\mathrm{q} / \mathrm{n}$ where $\mathrm{q}$ is the number of poor leaving with less then USD2 per day and $\mathrm{n}$ is the population.

25 The income gap ratio $\mathrm{I}=\sum \frac{g(i)}{q z}$ with $\mathrm{g}(\mathrm{i})=\mathrm{z}$-yi (difference between the poverty line and the income), represents the depth of poverty meaning the mean distance separating the poorest income from the poverty line.
} 
enterprises able to enter the market and to trade their goods and services, and, on the other hand, their impact on the economy of the region.

Fig. 12 - Default

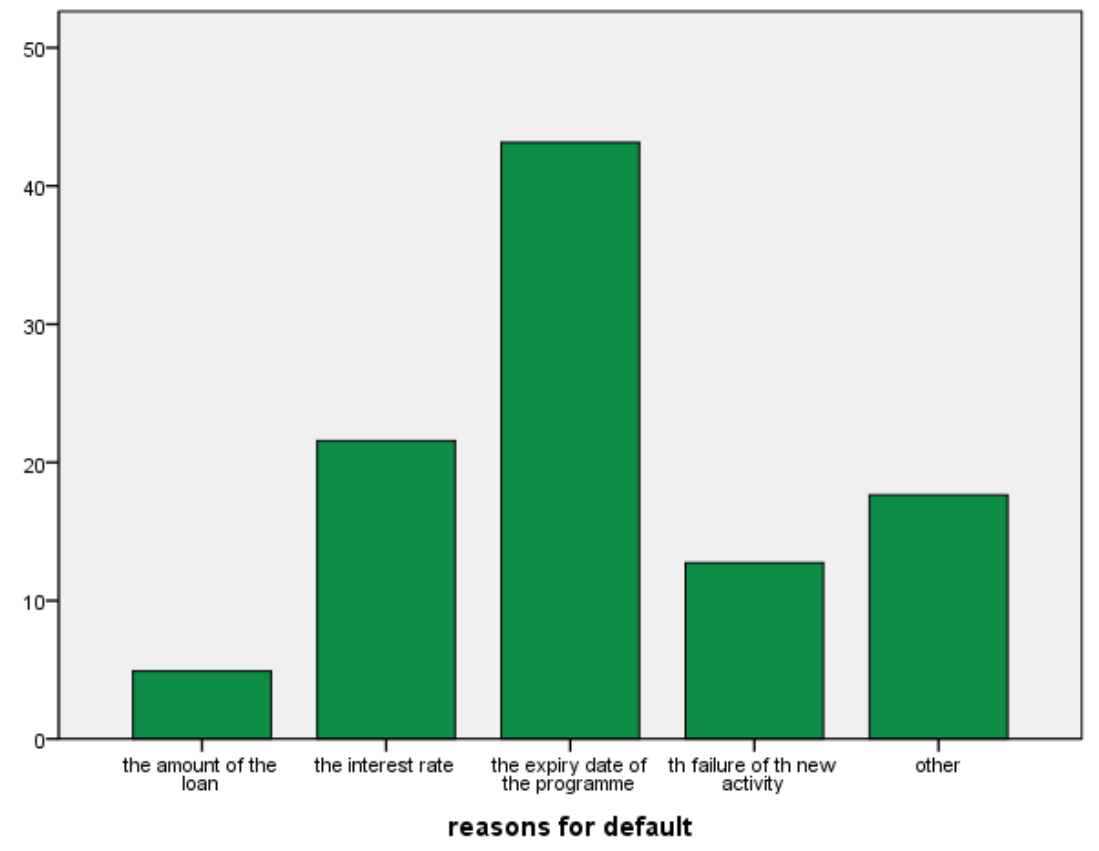

Source: Elaborations on survey data

\section{Savings}

Previous literature (Richardson and Oliva 2000; De Silva, 2012) underlines both the potential and the need of savings for poor people. Concerning microfinance clients, savings are compulsory in order to access the credit. Besides, it is also interesting to check the increase of non-compulsory savings and the use of them.

Our dataset shows that savings increased on average from 16,000 shillings (USD 6) to 44,000 (USD 17) per-month, meaning an increase of $275 \%$, with a slight bigger increase for women than for men. $77 \%$ of the clients were already able to save before the program and after the program $99 \%$ of clients have been able to save. In very few cases they saved less after entering the program (five observations).

It is really interesting to check the use they made of the money saved. Figure 13 shows the first option that they have selected. A gender analysis of the use of saving finds that the highest percentage of clients used their saving to improve existing activities (almost 30\%), and this is true for both men and women. Besides this finding, female clients used savings more for health and food, whereas men used them for house improvements.

A positive and significant correlation (0.01) has been found between savings amount per week after the program and the amount disbursed by the credit officers for second, third and forth loans; the correlation between saving and first loan amount disbursed is significant at 0.05 . 


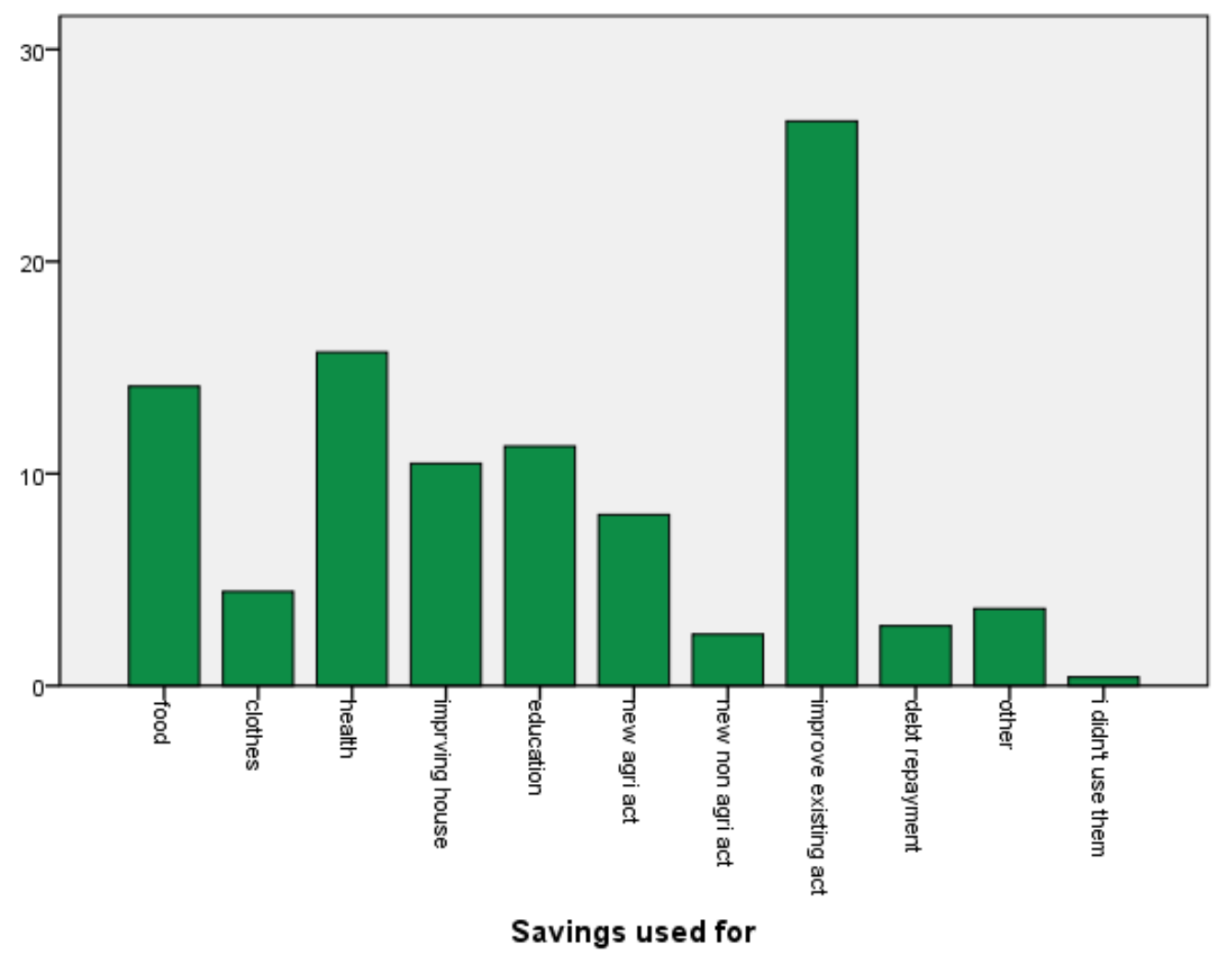

Source: Elaborations on survey data

\section{Consumption and house improvement}

Before entering the program almost $50 \%$ of the clients had troubles in providing a proper daily meal. After entering the program around $40 \%$ of this people solved their food consumption troubles; $22 \%$ of the sample declared they still have troubles in supplying daily food consumption to their households.

A key indicator to identify the level of poverty among household is the House Index. According to the Microcredit summit campaign, house improvements are considered as an outcome of microfinance. Regarding our sample, $77 \%$ of clients interviewed have been able to make important improvements in their house. The details offered by interviewees about the progresses made show how deep is the state of poverty of these family: many of them have been able to build an house, to buy beds, windows, doors, chairs, to put a roof in their habitations, plastering electricity, and others bought radio, fridge or a bicycle.

\section{VII - A Women Empowerment Indicator: Methodology and Findings}

One major point of debate with regard to empowerment is its measurement. Kabeer (1999) stresses that women's empowerment is about the process by which those who have been denied the ability to make strategic life choices acquire such ability. She underlines the importance of understanding empowerment as a process and not as an instrumentalist form of support, which requires measurement and quantification of empowerment.

However, in order to study the impact of microfinance on women's empowerment, there is a clear need for appropriate indicators that can measure it, but this seems to be a difficult task. For example, Malhotra (2002) underlines that even after emphasizing empowerment as a primary development goal, 
the major development agency have not developed a rigorous method for measuring and tracking changes in the levels of empowerment.

Apart from the classical methods such as Gender Development Index (GDI), Gender Empowerment Measure (GEM), quantitative surveys, ethnographic investigations, focus group discussions and case studies, several authors have tried to construct alternative indices of empowerment related to microfinance activity. Ackerly (1995) constructed an accounting knowledge indicator. Goetz and Sen Gupta (1996) built an index of managerial control on the use of loans, contributions in terms of labour to the financed activity. Hashemi, Schuler and Riley (1996) investigated the change in women's empowerment by creating an empowerment indicator built on the following criteria: mobility, economic security, ability to make small purchases, large purchases, involvement in major household decisions, relative freedom from domination by the family, political and legal awareness, and participation in public protests and political campaigns. Cheston and Kuhn (2002) underlines that certain measures of empowerment such as decision-making or self-confidence are very difficult to measure.

As underlined in the literature review, apart from an economic improvement in women's lives, what really matters in terms of empowerment is an increased women's power in terms of decision making in the social and economic context of their reference community/villages, as well as in their participation in decisions concerning investment and consumption within their family.

To test the women's empowerment as an outcome of the participation to the program, we have first built an indicator, based on an adapted version of Corsi (2008).

The indicator involves the following six aspects of social, household and individual life of Wekembe's female clients:

- chances to go out (for working, studying, taking care of your health, having fun)

- role within the reference community

- participation to the social and civil life of community/village/country

- ability in doing purchases without asking permission

- participation to the decisions concerning investment within the family (e.g. regarding purchases of livestock, vehicles, house repairs or rental of the land)

- bargaining power inside the household

For each one of the aspects under study, it has been built an indicator to check the change happened in their lives ascribable to the participation to the program. Each answer received a score of " -1 " if the initial condition has got worse, " 0 " if stayed the same, " +1 " if improved. The composite Index has been built combining the average score of each aspect under analysis. The final Index is then included between -100 and 100, with 100 as better score. Table 6 shows the results of the single indicators and the final Empowerment Index.

Table 6 - Empowerment Index

\begin{tabular}{|l|c|}
\hline Sub-questions & Empowerment dimensions \\
\hline A & 75 \\
\hline B & 72 \\
\hline C & 76 \\
\hline D & 46 \\
\hline E & 76 \\
\hline F & 70 \\
\hline Empowerment Index & $\mathbf{6 9 . 2}$ \\
\hline
\end{tabular}

Source: Elaborations on survey data 
As expected, the final Index is positive and shows a high score: 69.2. Checking for the sub-indicators we see that the lowest improvement has been realized in terms of ability in doing purchases without asking for permission. This is a pretty negative evidence of the owning and control of money inside the family. Even if the sub-indicator is positive and high, this low score achieved can remind of one of the main evidences found in the literature, namely, the misappropriation by the men of their women's loans. In fact, when we deepen the analysis of this question we find that $18 \%$ of female clients declared a decreasing on their ability in doing purchases without asking for permission. If we compare this result to the other questions, which, on average, show only $2 \%$ of women stating a decrease in their power, we have a better picture of how the studied microfinance program confirm the theory regarding this dimension of empowerment.

The sub-question concerning the chance of going out clarify the reasons why they have increased that chance: $70 \%$ of the female clients declared to have more free time to go out for working purpose, which may means that they have not free time to go out because they are busy with their activities. It can also mean that they cannot go out for fun even if they have time. However, the second option selected, gave different results: $70 \%$ of them declared to have more time for taking care of their health, the $32 \%$ of them for education and just the $7 \%$ for fun. We can then state that they perceive more freedom in their decision of going out since when they have entered the program.

Table 7 - Use of the time to go out gained from the participation to the program

\begin{tabular}{|l|c|c|}
\hline & Percentage & Valid Percentage \\
\hline Work & 34.4 & 66.9 \\
\hline Education & 8.5 & 16.6 \\
\hline Health & 7.1 & 13.9 \\
\hline Fun & 1.4 & 2.6 \\
\hline Total & 51.4 & 100.0 \\
\hline Missing & 48.6 & \\
\hline
\end{tabular}

Source: Elaborations on survey data

\section{VIII - Impact Evaluation: methodology}

As we have seen in the introduction and in the literature review, impact evaluation of microfinance is a main methodological issue. To the best of our knowledge, this is the first attempt to evaluate the impact of microfinance by means of a Generalized propensity score matching technique.

In the following section we show the methodology applied to check if the statistical findings about women empowerment improvement and savings increase are ascribable to the microfinance treatments, or whether they are just the results of a clients perception about their involvement in the microcredit program.

The influence of treatment variables, namely, the number of loans received and the average loan size disbursed, on women empowerment and savings is first assessed by regression model. We then doublecheck the results of the influence on savings, controlling for selection bias, by means of a Generalized Propensity Score matching technique.

Table 8 shows the descriptive statistics of the variables involved in the analysis. 
Table 8 - Descriptive statistics

\begin{tabular}{|c|c|c|c|c|c|}
\hline & $\mathbf{N}$ & Minimum & Maximum & Mean & $\begin{array}{c}\text { Standard } \\
\text { Dev. }\end{array}$ \\
\hline Sex (a) & 291 & 0 & 1 & 0.70 & 0.459 \\
\hline Civil status (b) & 287 & 0 & 1 & 0.52 & 0.500 \\
\hline Family members & 253 & 0 & 16 & 4.80 & 2.756 \\
\hline Age & 235 & 18 & 78 & 35.7 & 12.394 \\
\hline Literacy $(\mathrm{c})$ & 283 & 0 & 1 & 0.88 & 0.326 \\
\hline Saving amount per week before the program & 262 & 0 & 170,000 & 13,267 & 24,474 \\
\hline Monthly income & 243 & 0 & $1,000,000$ & 295,123 & 229,722 \\
\hline Average amount disbursed & 265 & 7,4 & $1,500,000$ & 480,064 & 255,862 \\
\hline Number of loans & 291 & 1 & 17 & 2.86 & 2.141 \\
\hline
\end{tabular}

Notes: (a) $0=$ Male; $1=$ Female

(b) $0=$ Single, Separated/Divorced, Widowed; $1=$ Married

(c) $0=$ Illiterate; $1=$ Literate

\section{Linear regression analysis}

The following models have been tested:

(1) $\operatorname{Reg}(E I F)=b 1 F M+b 2 a g e+b 3 a l p h+b 4 i n c+b 5$ nloans $+b 6 A L S+\epsilon_{i}$

(2) $\operatorname{Reg}(E I C)=b 1 F M+b 2 a g e+b 3 a l p h+b 4 i n c+b 5 n l o a n s+b 6 A L S+\epsilon_{i}$

(3) $\operatorname{Reg}(\log G R S)=b 1$ sex $+b 2 F M+b 3 a g e+b 4 a l p h+b 5 \operatorname{loginc}+b 6$ logsaveb +

$$
\text { b7nloans }+b 8 \log A L S+\epsilon_{i}
$$

The dependent variables tested in equation (1) and (2) are a standardized version of the index of empowerment inside the family (EIF) and inside the reference community (EIC). The index discussed in Section VI has been divided here into two sub-indexes. According to the literature (Corsi, 2008), our purpose is to check the different influences of microfinance treatments on the empowerment of women regarding their family environment as well as their reference community/village.

The two variables have been built from the answers given to the following questions:

Since when you entered the program (chose among 1.Decreased greatly 2.Decreased 3. Stayed the same 4 . Increased 5. Increased greatly):

Empowerment inside the family:

- Your chances to go out (for working, studying, taking care of your health, having fun) have....

- Your ability in doing purchases without asking permission has....

- Your participation to the decisions concerning investment within your family (for example regarding purchases of livestock, vehicles, house repairs or rental of the land) has......

- Your bargaining power inside the household has.....

Empowerment inside the community:

- Your role within you reference community has....

- Your participation to the social and civil life of your community/village/country has..... 
According to the literature (Noreen, 2011), we have selected four control variables affecting women's empowerment: ${ }^{26}$ the number of family members, the alphabetization, the age and the income earned by women and we have assumed a liner relation.

The dependent variable tested in equation 3 is the growth rate of savings (GRS), which has been built using clients' answers to the following questions: ${ }^{27}$

- How much are you able to save in a month? (Savings t1)

- How much were you able to save in a month before entering the programme? (Savings t0)

$$
G R S=\frac{\text { Savings } t 1-\text { Savings } t 0}{\text { Savings } t 0}
$$

Coefficients $b 1-b 6$ evaluate the effect of the controlling variables chosen according to the theory: client sex, family members, age, alphabetization, savings before the program and income; coefficients $b 7-b 8$ evaluate the impact of the treatment variables.

We assumed a parametric linear relation and we then checked the same relation with a non parametric technique (GPS).

We will discuss the results in the following section.

\section{GPS Analysis}

Due to the high cost of field research, we had to concentrate our survey on the treated group, ${ }^{28}$ so that we had to face the limitation related to the lack of a control group in our sample. Those who participate in microfinance programs are claimed to be more entrepreneurial and wealthier than others (Karlan, 2001), it is then difficult to assess that the impact on outcomes, in this case on the growth rate of savings, is ascribable to the treatment received rather than to the clients' own characteristics. At the same time, the selection process of the MFIs can also, sometimes, be driven by bias regarding, for example, sex (Agier and Szafarz, 2013), education, marital status (married people may be considered more trustable because they can be guaranteed by their wives/husbands) and many others.

In order to address the selection bias issue and test the robustness of our previous findings on savings, we have applied a novel method, namely, a Generalized Propensity Score matching (GPS). Originally proposed by Hirano and Imbens (2004) and Imai van Dick (2004), the GPS is a non-parametric impact evaluation technique, which allows controlling for selection bias when a control group is lacking and the treatment takes on a continuum of values..$^{29}$

After having used the linear regression model in order to test the influence of the treatment variables to the growth rate of savings, we then applied non parametric impact evaluation technique to test two further models related to the two treatment variables under analysis in this exercise: the average amount of loan disbursed to each clients over the period spent inside the program ( $1^{\text {st }}$ model $)$ and the number of loans received $\left(2^{\text {nd }}\right.$ model). The outcome variable tested is the growth rate of savings. We selected a set of clients' observable characteristics able to explain the probability of receiving the treatment. According to the literature (Agier and Szafarz, 2013) and the availability of information we were able to collect through our survey, the selected variables affecting the intensity of treatment are: client's sex, age, marital status, number of family member, alphabetization and, finally, the amount of savings they have been able to keep monthly before entering the microfinance program.

\footnotetext{
${ }^{26}$ Unfortunately we had too missing values for the variable "education of husband", which the theory considers fundamental, so that we could not include it in the equation, even if in further analysis we would like to insert it.

${ }^{27}$ According to the credit officers, this answer has been given comparing their current ability to save with the previous one. We didn't find useful to actualize the value of the savings before the program.

${ }^{28}$ Further researches will be conducted in order to update our dataset, including also a control group.

${ }^{29}$ For a methodological discussion, see Hirano and Imbens (2004), Imai van Dick (2004), Bia and Mattei (2008).
} 
The first step consisted in estimating the conditional distribution of the treatment, given the covariates. ${ }^{30}$ The second step is aimed at testing the balancing property. The combination of the balancing property and the unconfoundedness assumption implies that the assignment of the treatment is uncounfounded, given the GPS (Hirano and Imbens, 2004). To this end, we formed three groups of approximately the same size on the basis of the actual treatment intensities and two blocks of GPS values for each group. Balancing is assessed by comparing, within each block, each covariate mean of the treatment group $j$ with the corresponding covariate mean of the other $j-1$ treatment groups combined. The mean differences of each of the blocks are then combined as a weighted average - with weights given by the number of observations in the respective block - and used as a t-statistics for evaluating the balancing of each covariate in the given treatment group (Hirano and Imbens, 2004). In our case, according to a standard two-sides t test, balancing was satisfied at 0.10 level in the first model, and at the 0.05 level in the second one. The third step was finally the estimation of the dose-response functions, by averaging the conditional expectations of the outcomes over the GPS at any particular level of the treatment, and the corresponding treatment effect functions, i.e., the first derivatives of the respective dose-response functions. A number of polynomials can be tested for the above relationships. Among the alternatives, in our sample the linear one turned to be the more robust one. This is not surprisingly since, as our object of study are the poorest clients, we are indeed looking at the initial stages of savings' growth that are supposed to be characterized by a steeper incline.

\section{IX - Results}

The first two models show very similar results (see Table 9). According to the literature (Noreen, 2011; Caldwell et al., 1982), women's empowerment increases by ageing as they have more life experience. Our analysis confirms this finding: being one year older increases, ceteris paribus, both empowerment indexes; however, it has a stronger influence on the index referring to the empowerment inside the community than on the same index inside the family. It increases the first by 0.409 whereas it increases EIF by 0.039 . Moreover, we find that having one additional family member (which means more children) increases women empowerment, both inside the family and the community, by 0.02 .

Instead, the two models show different results concerning the variables literacy. It is strongly significant (at 1\%) in the first model (being literate increases EIF by 0.374), while it is not statistical significant regarding EIC. This result is in line with the economic view, which states that education's impact is important to strengthen the female's role in the relationship between wife and husband.

The influence of the variable income is not relevant in both models.

Controlling for the variables above, we can focus on the influence of the treatment variables on both indexes. Models 1 and 2 show similar results, the average loan size is not significant, while the number of loans is significant at $\%$ : one more obtained loan increases, ceteris paribus, the value of both indexes by around 0.035 .

Table $9-$ Model 1 and 2 outcomes

\begin{tabular}{|l|l|l|l|l|}
\hline & \multicolumn{2}{|c|}{$\begin{array}{c}\text { Dependent Variable: Emp. inside } \\
\text { the Family }\end{array}$} & \multicolumn{2}{c|}{$\begin{array}{c}\text { Dependent Variable: Emp. inside the } \\
\text { Community }\end{array}$} \\
\hline Family Members & 0.021 & $(0.008)(* *)$ & 0.020 & $(0.006)(* *)$ \\
\hline Literacy & 0.374 & $(0.067)(* * *)$ & 0.017 & $(0.014)$ \\
\hline Age & 0.039 & $(0.015)(* *)$ & 0.409 & $(0.064)(* * *)$ \\
\hline
\end{tabular}

\footnotetext{
30 A zero-skewness log transformation of the treatment variable has been applied. The normal distribution assumption of the treatment given the covariates is suitable according to the residual analysis of the first stage specification: the Kosmogorov-Smirnov test does not reject the null hypothesis of normal distribution.
} 


\begin{tabular}{|l|l|l|l|l|}
\hline Income & $2.30 \mathrm{e}-07$ & $(8.77 \mathrm{e}-08)(* *)$ & $1.15 \mathrm{e}-07$ & $(8.38 \mathrm{e}-08)$ \\
\hline Average Amount disbursed & $-2.79 \mathrm{e}-08$ & $(6.86 \mathrm{e}-08)$ & $4.83 \mathrm{e}-08$ & $(6.73 \mathrm{e}-08)$ \\
\hline Number of loans & 0.034 & $(0.0122)(* *)$ & 0.038 & $(0.011)(* *)$ \\
\hline N. obs & 99 & & 102 & 0.84 \\
\hline $\mathrm{R}^{2}$ & 0.84 & & \\
\hline $\begin{array}{l}\text { Linear regression with robust standard errors. } \\
\text { Standard Errors in parentheses: * significant at 10\% ** significant at 5\% *** significant at 1\% level }\end{array}$ \\
\hline
\end{tabular}

Source: Elaborations on survey data.

The outcome of the third model is not different from the others (see Table 10): it evidences a positive and statistically significant influence of the treatment number of loans on the dependent variable, that is the growth rate of savings, while the influence of the variable average loan size disbursed on the growth rate of savings is not significant. An increase of one received loan increases, ceteris paribus, the growth rate of savings by $17.4 \%$. Moreover, the variable sex has a positive significant influence, so that being women increases, ceteris paribus, the growth rate of savings by $42.2 \%$. This finding confirms the economic view, which underlines that women care more about the household compared to men and they are more prudent about the use of money.

As expected, an increase of one percent of income increases the growth rate of savings by $0.002 \%$, whereas the variable savings amount before the program has a negative influence on the growth rate of savings, which indicates that clients with higher saving levels have lower growth rate of savings after entering the program.

The variable literacy has a negative influence on the growth rate of savings; the smaller extra-saving could be explained with the fact that literate clients apply a more efficient employ of their resources (i.e. a better consumption smoothing).

The results of the three models suggest that the impact of microfinance on clients' lives is ascribable to the availability of credits and the continuity of the participation into the program, rather than to the loan size.

Table 10 - Model 3 outcome

\begin{tabular}{|l|l|l|}
\hline Dependent Variable: Growth rate of saving in log & $\begin{array}{l}\text { R } 0.343 \\
\text { N.obs. 118 }\end{array}$ & $(0.193)(* *)$ \\
\hline Client Sex & 0.422 & $(0.034)$ \\
\hline Family Member & -0.021 & $(0.948)(* *)$ \\
\hline Literacy & -1.903 & $(0.078)$ \\
\hline Age & -0.097 & $(0.116)(* *)$ \\
\hline Log Income & 0.263 & $(0.071)(* * *)$ \\
\hline Saving before the program log & -0.298 & $(0.178)$ \\
\hline Average Amount disbursed in log & -0.001 & $(0.067)(* *)$ \\
\hline Number of loans & 0.174 & \\
\hline
\end{tabular}


Linear regression with robust standard errors.

Standard Errors in parentheses: * significant at 10\% ** significant at 5\% *** significant at 1\% level

Source: Elaborations on survey data.

Our GPS outcome address self-selection. As a result, both GPS terms are statistically significant, meaning that selectivity actually matters for unmatched observations (i.e., in the sample there is unobserved heterogeneity in treatment propensity related to the outcome). However, our doseresponse function confirms the above empirical evidence, i.e., while the impact of the average loan size is close to zero ,the number of loans actually has a causal influence on the growth rate of savings (see Table 11) It confirms previous findings: there is an impact of microfinance on growth rate of savings, which is ascribable to the participation to the program rather than to the loan size received..

Table 11 - GPS outcome

\begin{tabular}{|c|c|c|c|c|}
\hline & \multicolumn{2}{|c|}{$1^{\text {st }}$ Model } & \multicolumn{2}{|r|}{$2^{\text {nd }}$ Model } \\
\hline & \multicolumn{2}{|c|}{ Treatment: Average loan size } & \multicolumn{2}{|c|}{ Treatment: Number of loans } \\
\hline $\mathrm{T}$ & $8.64 \mathrm{e}-07$ & $(2.44)(* *)$ & 0.3390 & $(1.90)\left(^{*}\right)$ \\
\hline GPS & 1.02261 & $(3.38)(* * *)$ & -1.014724 & $(4.98)(* * *)$ \\
\hline $\mathrm{T}^{*} \mathrm{GPS}$ & $-2.01 \mathrm{e}-06$ & $(6.73 \mathrm{e}-07)(* *)$ & 0.117095 & $(.16)$ \\
\hline Balancing property & \multicolumn{2}{|c|}{ Satisfied at 0.10} & \multicolumn{2}{|c|}{ Satisfied at 0.05} \\
\hline N. obs & 116 & & \multicolumn{2}{|l|}{120} \\
\hline $\mathrm{R}^{2}$ & 0.17 & & \multicolumn{2}{|l|}{0.08} \\
\hline theses: $* \mathrm{~s}$ & gnifica & k* significant & & \\
\hline
\end{tabular}

Source: Elaborations on survey data.

\section{$\mathrm{X}$ - Conclusions}

According to the main poverty indicators, Wekembe's clients are among the poorest in Kampala area; in fact, around $35 \%$ of clients of our sample live with less than USD 2 per day and according to the Income gap ratio the average income of the poorest client of Wekembe is $78 \%$ far from the poverty line. For the best of our knowledge, concerning the poverty outreach mission, Wekembe can be defined as a high performing program compared to the microfinance industry in Uganda and outside the country. ${ }^{31}$

Wekembe's integrated approach results in a positive "perceived" impact on the achievement of empowerment, improving clients' savings, income, consumption and housing.

In terms of savings, our dataset shows that savings propensity increased on average from 16,000 to 44,000 shillings, that means, almost a three times increase (275\%). We also find a slight bigger increase for women then for men, which is an important result in term of empowerment, as women are considered more vulnerable than men.

If $77 \%$ of the clients were already able to save before the program, after the program the same data increases to $99 \%$ of clients. Female clients are more prone to save mainly for health and education

${ }^{31}$ According to the literature, MFIs' clients in Uganda are not among the poorest. See AMFIU (2008). 
purpose while men save for house improvements. This finding reminds of the economic view that women are more concerned than men about the family well-being. We find a positive and significant correlation (0.01) between the savings amount per week after the program and the amount disbursed.

Consumption and housing are good proxies of microfinance's impact on clients' well being. Before entering the program, almost $50 \%$ of the clients had troubles in having proper daily meal, whereas after entering the program, around $40 \%$ of this people solved their food consumption troubles. Finally, $77 \%$ of clients interviewed have been able to make important improvements in their houses.

The Empowerment Index score (69.2) is positive and high, which shows a positive perception of female clients about the impact of the program on several aspects of their personal empowerment: in terms of decision-making inside and outside the household, of their freedom to choose for their free time, as well as of their freedom to purchase goods or services for their family-enterprises.

If we look at the impact of microfinance on socio-economic aspects of Wekembe' clients, we find different results depending on the treatment variable used, namely, number of loans and average loan size disbursed. The econometrical analysis on women's empowerment and on the growth rate of their savings evidences the significant effect of the number of loans as a treatment proxy, whereas the loan size seems not to be significant. This suggests that the impact of microfinance on clients' lives is ascribable to the availability of credits and the continuative participation into the program, rather than to the loan size.

Controlling for self-selection in treatment assignment by means of a Generalized Propensity Score Matching (GPS), we find similar impact results on savings propensity. In fact, only the number of loans shows a strong positive impact, whereas the average loan size impact is close to zero.

Further research is needed in order to assess the robustness of these results. In detail, future research includes developing a dataset updating after one year and after the implementation of a training model to strengthen Wekembe's performance; another research's line would be improving the quality of some questions in order to understand better the situation of the clients; finally, a panel data can be created. A sample with same characteristics of ours could be helpful to check for social-economic improvements without microfinance, in order to assess the robustness of other findings apart from those related to savings. 


\section{References}

AMFIU (2008), Uganda Microfinance Industry Assessment, Association of Microfinance Institutions of Uganda (AMFIU).

Armendariz de Aghion B. and Morduch J. (2005), The Economics of Microfinance, MIT Press.

Armendáriz de Aghion B. and Morduch J. (2003), "Microfinance: Where Do We Stand?”, in Goodhart C. (ed.), Financial Development and Economic Growth: Explaining the Links, Basingstoke, Hampshire: Palgrave Macmillan.

Asim S. (2008), "Evaluating the Impact of Microcredit on Women's Empowerment in Pakistan", CREB Working Paper, no. 2-9.

Banerjee A., Duflo E., Glenerster G. and Kinnan C., (2013), "The Miracle of Microfinance? Evidence from a Randomized Evaluation”, MIT Department of Economics Working Paper, no. 5993.

Banerjee A., Duflo E., Glenerster G. and Kinnan C., (2010), "The Miracle of Microfinance? Evidence from a Randomized Evaluation”, MIT Department of Economics Working Paper, no. 4162.

Balkenhol B. (2006), "The Impact of Microfinance on Employment: What Do We Know", paper prepared for the Global Microcredit Summit 2006.

Barnes C. and Morris G. (2005),"An Assessment of the Impact of Microfinance A Case Study from Uganda”, Journal of Microfinance, Vol. 7, no. 1, pp. 39-54.

Barnes C., Morris G. and Gaile G. (1999), "An Assessment of Clients of Microfinance Programs In Uganda", International Journal of Economic Development, Vol. 1, no. 1, pp. 80-121.

Barnes,C., Morris G. and Gaile G. (1998), An Assessment of the Impact of Microfinance Services in Uganda: Baseline Findings, Vol. 1 and Vol. 2, USAID AIM Project.

Barnes C., Gaile G. and Kibombo R. (2001), "The Impact of Three Microfinance Programs in Uganda", AIMS paper, Washington, DC: Management Systems International.

Barr M. (2005), "Microfinance and Financial Development", Michigan Journal of International Law, Vol. 26, pp. 271-296.

Bartlet J., Kotrlik J. and Higgins C. (2001), "Organizational Research: Determining Appropriate Sample Size in Survey Research", Information Technology, Learning, and Performance Journal, Vol. 19, no. 1.

Batbekh S. and Blakburn K. (2008), "On the Macroeconomics of Microfinance", The University of Michigan - Discussion paper series, no. 106.

Bateman M. (2011), "Microfinance as a Development and Poverty Reduction Policy: Is It Everything It's Cracked up To Be?”, Background Note, Overseas Development Institute, March 2011.

Beck T., Levine R. and Loayza N. (2000), "Finance and the Sources of Growth", Journal of Financial Economics, Vol. 58, pp. 261-300.

Bia M. and Mattei A. (2008), "A Stata Package for the Estimation of the Dose-response Function through Adjustment for the Generalized Propensity Score", The Stata Journal, Vol. 8, no. 3, pp. 354-373.

Calidoni-Lundberg F. and Fedele A. (2006), "Technology Replaces Culture in Microcredit Markets: the Case of Italian MAGs", Working Paper 20060902, Department of Statistics, University of Milan-Bicocca.

Carlton A., Manndorff H., Obara A., Reiter W. and Rhyne E. (2001), Microfinance in Uganda, published by the Austrian Federal Ministry of Foreign, Department for Development Cooperation.

Cheston S. and Kuhn L. (2002), "Empowering Women through Microfinance", Opportunity International. 
Ciravegna D. (2006), "The Role of Microcredit in Modern Economy: the Case of Italy", Flacso Working Paper, Costa Rica.

Claessens S. and Perotti E. (2005), "The Links between Finance and Inequality: Channels and Evidence", Journal of Comparative Economics, Vol. 35, Issue 4, pp. 748-773.

Clarke G., Xu C.L. and Zou H. (2003), "Finance and Income Inequality: Test of Alternative Theories", World Bank Policy Research Working Paper, no. 2984.

Conzo P. and Becchetti L. (2010), "The Controversial Effects of Microfinance on Child Schooling: a Retrospective Approach", ECINEQ WP, no. 2010 - 173.

Corsi M. (ed.) (2008), Donne e microfinanza. Uno sguardo ai paesi del Mediterraneo, Aracne editrice, Rome.

Corsi M. et al. (2006), "Women and Microfinance in Mediterranean Countries", Development, Vol. 49, no. 2, pp. 67-74.

Cuong N., Bigma D., Van den Berg M. and Thieu V. (2007), "Impact of Microcredit on Poverty and Inequality: The Case of the Vietnam Bank for Social Policies", Paper submitted to "Microfinance: What Do We Know?", December 7-8 2007, Groningen, The Netherlands.

De Luca A. (1990), Metodi statistici per le ricerche di mercato, Utet Libreria, Torino.

De Silva I. (2012), "Evaluating the Impact of Microfinance on Savings and Income in Sri Lanka: Quasiexperimental Approach Using Propensity Score Matching", The Journal of Applied Economic Research, Vol. 6, no. 1, pp. 47-74.

Du J. and Girma S. (2009), "The Effects of Foreign Acquisition on Domestic and Export Markets Dynamics in China", The World Economy, Vol. 32, no. 1, pp.164-177.

Dunford C. (2006), "Evidence of Microfinance's Contribution to Achieving the Millennium Development Goals. Freedom from Hunger", Microfinance Information Exchange - Working Paper, no. 35795.

Duflo E. (2011), “Women's Empowerment and Economic Development”, Journal of Economic Literature, Vol. 50, no. 4, pp. 1051-1079.

Eschenbach F. (2004), "Finance and Growth: A Survey of the Theoretical and Empirical Literature", Tinbergen Institute Discussion Paper, no. TI 2004039/2.

Ferro Luzzi G. and Weber S. (2006), "Measuring the Performance of Microfinance Institutions", Haute école de gestion de Genève - Cabier de Recherche, no. HES-SO/HEG-GE/C—06/3/1—CH.

Goetz A.M. and Sen Gupta R. (1996), "Who Takes the Credit? Gender, Power, and Control over Loan Use in Rural Credit Programs in Bangladesh", World Development, Vol. 24, no. 1, pp.45-63.

Goldberg N. (2005), Measuring the Impact of Microfinance: Taking Stock of What We Know, Grameen Foundation USA.

Guérin I. (2002), La Microfinance et la création d'entreprise par le chomeurs. La situation dans quelques pays européens et en Amérique du Nord, Rapport pour le Bureau International du Travail.

Hashemi S. M., Schuler, S. R. and Riley A. P. (1996), "Rural Credit Programs and Women's Empowerment in Bangladesh", World Development, Vol. 24, no. 4, pp. 635-653.

Hermes N. and Lensink R. (2007), "The Empirics of Microfinance: What Do We Know?”, The Economic Journal, Vol. 117, Issue 517, pp. F1-F10.

Hirano K. and Imbens G. (2004), "The Propensity Score with Continuous Treatments", in Gelman A. and Meng X. L. (eds.), Missing Data and Bayesian Methods in Practice: Contributions by Donald Rubin's Statistical Family, New York: Wiley.

Hoff K. and Stiglitz J.E. (1990), “Imperfect Information and Rural Credit MarketsPuzzles and Policy 
Perspectives", The World Bank Economic Review, Vol. 4, no.3, pp. 235-250.

Holvoet N. (2005), "The Impact of Microfinance on Decision-Making Agency: Evidence from South India", Development and Change, Vol. 36, no. 1, pp. 75-102.

Hosseid J. and Kirkpatrick C. (2002), "Financial Development and Poverty Reduction in Developing Countries", International Journal of Finance and Economics, Vol. 7, pp. 97-108.

Hudon M. (2008), "Norms and Values of the Various Microfinance Institutions", CEB Working paper, no. $08 / 006$.

Hulme D. (2000), "Impact Assessment Methodologies for Microfinance: Theory, Experience and Better Practice", World Development, Vol. 28, Issue 1, pp. 79-98

Hulme D. and Mosley P. (1997), "Finance for the Poor or the Poorest? Financial Innovation, Poverty and Vulnerability" in Wood G.D. and Sharif I. (eds.), Who Needs Credit? Poverty and Finance in Bangladesh, University Press Limited, Dhaka, 1997, and Zed Books, UK,

Hulme D. and Mosley P. (1996), Finance against Poverty, Vols. 1 and 2, London: Routledge.

ILO (2002), Microfinance in Industrialized Countries, Helping the Unemployed to start a Business, Geneva, Switzerland.

Imai K, Arun T. and Annim S. (2010), "Microfinance and Household Poverty Reduction: New Evidence from India”, World Development, Vol. 38, no. 12, pp. 1760-1774.

IMF (2012), Enhancing Financial Sector Surveillance in Low Income Countries (Lics) - Case Studies, International Monetary Fund.

Kai H. and Hamori S. (2009), "Microfinance and Inequality", Research in Applied Economics, Vol. 1, no. 1, pp. 1-12.

Kabeer N. (2001), "Reflections on the Measurement of Women's Empowerment”, Sida Studies, no. 3.

Kabeer N. (1999), "Resources, Agency, Achievements: Reflections on the Measurement of Women's Empowerment", Development and Change, Vol. 30, no. 3, pp. 435-464.

Kabeer N. (1997), "Women, Wages and Intra-household Power Relations in Urban Bangladesh", Development and Change, Vol. 28, pp. 261-302.

Kluve J., Schneider H., Uhlendor A. and Zhao Z. (2012), "Evaluating Continuous Training Programs by using the Generalized Propensity Score", Journal of the Royal Statistical Society, Vol. 175, no. 2, pp. 587-617.

Krishna A. (2003), "Social Capital, Community Driven Development, and Empowerment: A short note on concepts and operations", World Bank working paper, no. 33077.

Lafourcade A., Isern J., Mwangi P. and Brown M. (2005), Overview of the Outreach and Financial Performance of Microfinance Institutions in Africa, Microfinance Information Exchange, April 2005.

Lapenu C. et al. (2004), "Performances sociales : Une raison d'être des institutions de microfinance et pourtant encore peu mesurées. Quelques pistes", Mondes en Développement, Vol. 32, no. 126, pp. 51-58.

Lawko A. (2006), Microfinance, Rural Livelihoods, and Women's Empowerment in Uganda, Research report, African Studies Centre, Leiden.

Levine R., (1996), "Financial Development and Economic Growth”, Policy Research Working Paper Series, no. 1678.

Levine R. and King R. (1993), "Finance and Growth: Schumpeter Might be right", Policy Research Working Paper Series, no. 1083. 
Malhotra A. (2002), "Measuring Women's Empowerment as a Variable in International Development", paper prepared for the World Bank workshop "Poverty and Gender: New Perspectives", Washington D.C.

Matovu J. et al. (2011), Assessing Development Strategies to Achieve the MDGs in Republic of Uganda, United Nations Department for Social and Economic Affairs.

Mayoux L. (2006), “Women's Empowerment and Microfinance: A 'Think Piece' for the Microfinance Field", mimeo.

Mayoux L. (2001), "Tackling the Down Side: Social Capital, Women's Empowerment and Microfinance in Cameroon", Development and Change, Vol. 32, pp.435-464.

Mayoux L. (2000), "Microfinance and the Empowerment of Women: A Review of the Key Issues", International Labour Organization Working Paper, no. 23.

Mayoux L. (1997), “The Magic Ingredient? Microfinance and Women's Empowerment”, a Briefing Paper prepared for the Micro Credit Summit, Washington.

Mersland R. (2005), "The Agenda and Relevance of Recent Research in Microfinance", MPRA Paper, no. 2433.

Mersland R. and Øystein S.R. (2007), "Performance and Corporate Governance in Microfinance Institutions", MPRA Paper, no. 3888.

Metcalf H. and Benson R. (2000), "From Unemployment to Self-Employment: Developing an Effective Structure of Micro-Finance Support”, NIESR Discussion Paper, no. 170.

Magrini E., Montalbano P., and Nenci S. (2013), “Are the EU Trade Preferences Really Effective? A Generalized Propensity Score Evaluation of the Southern Mediterranean Countries' Case in Agriculture and Fishery", Working Papers Series, Department of Economic and Social Sciences, Sapienza University of Rome, n. 2/2013. Available at SSRN: http://ssrn.com/abstract=2302750 or http://dx.doi.org/10.2139/ssrn.2302750.

Magrini E., Montalbano P., Nenci S. and Salvatici L. (2013), "Agricultural trade distortions during recent international price spikes: What implications for food security?", Paper presented at the $54^{\text {th }}$ SIE Annual Conference, Bologna, 24-26 October. Available at http://www.siecon.org/online/wp-content/uploads/2013/09/Magrini-Montalbano-NenciSalvatici3.pdf

Morduch J. (1999), “The Microfinance Promise”, Journal of Economic Literature, Vol. 37, pp. 1569-1614.

Noreen S. (2011), "Role of Microfinance in Empowerment of Female Population of Bahawalpur District", 2011 International Conference on Economics and Finance Research, IPEDR, Vol. 4 (2011).

OECD (2012), African economic outlook 2012, Paris.

Rahman A. (1999), Women and Microcredit in Rural Bangladesh: Anthropological Study of the Rhetoric and Realities of Grameen Bank Lending, Westview Press, 1999.

Rahman A. and Da Vanzo J. (1997), "Influence of the Grameen Bank on Contraceptive Use in Bangladesh", Paper presented at a Population Council workshop on Measuring the Impact of Micro-credit Programs on Fertility, New York.

Ratnaparkhi M.V. and Krishnamurthy R. (2002), "Compositional Multivariate Time Series Analysis of the Savings and Loans by the Microfinance Institutions in Maharashtra State", Proc. IOAS Conf. London.

Simanowitz A. (2000), "Overcoming The Obstacles of Identifying The Poorest Families”, Microcredit Summit Campaign. 
Stiglitz J.E., Morshed A.K.M.M. and Emran S. (2007), "Microfinance and Missing Market", SSRN papers, no. 1001309.

Vani S. (2011), "Women's Empowerment and Microfinance. An Asian Perspective Study", IFAD, Occasional Paper.

Vanroose A. (2008), "What Macro Factors Make Microfinance Institutions Reach Out?” CEB Working paper, no. 08/036.

Vanroose A. (2007), “The Uneven Development of Microfinance: A Latin-America Perspective?”, CEB Working paper, no. 06/021.

World Economic Forum (2012), The Global Gender Gap Report.

Wright G. and Rippey P. (2003), "The Competitive Environment in Uganda: Implications for Microfinance Institutions and their Clients", Microsave document, no. 1.9.42374.

Zarazua M. and Johnson S. (2009), "Financial Access and Exclusion in Kenya and Uganda", Bath papers in international development, no. 1.

Zeller M. and Meyer. R. (2002), The Triangle of Microfinance: Financial Sustainability, Outreach and Impact, John Hopkins University Press, Baltimore and London. 


\section{Annex 1: Survey questionnaire}

A1. Nationality:

A2. Civil status:
1. Married
2. Divorced/separated
3. Widowed
4. Single

A3. How many people are in your household?

Housebold is defined in this context "as the unit of consumption: a unit which organizes the consumption of a collective fund of material goods. So defined, the household is sometimes called the "bearth-hold" in which all the members of the household are seen to share food from a common hearth" $\left.{ }^{32}\right]$

[Columns C, D and E do not correspond necessary to first, second and third child, but could refer to three other household members who provide more substantial income]

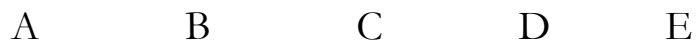

Self Husband 1st 2nd 3rd

A4. Age

Yes No

A5. Ability to read and write:

No

A6. Years of school attended:

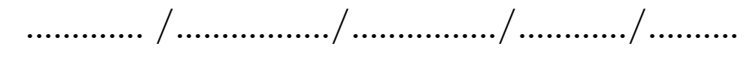

A7. Type of employment:

[In case of more than one employment, choose the activity funded by the loan]

1. Salaried work

1.a Temporary salaried work

2. Self-employed activity

3. Unemployed

4. Unable to work

5. Student

6. Housewife

A8. Field of work:

1. Farming

2. Animal husbandry

3. Industry

4. Commerce and Services

5. Handicraft

A9. Which is your monthly income?

If household's members providing income (other than interviewee and her husband) are more than 3, please add up those exceeding income in the column E $\left(3^{\text {rd }}\right)$ and report it in the questionnaire. Please report each household member total income, not only the income related to the activity funded by the loan]

${ }^{32}$ Chen M. A. and Dunn E. (1996), "Household Economic Portfolios", AIMS, Washington D. C. 
A10. Since you entered the programme, your revenue has:

1. Increased

2. Stayed the same

3. Decreased

A11. How long have you been in the program? (years)

A12. How did you know about the programme?
1. Through the grapevine
2. Media
3. Promoter (local agents)

\section{CREDIT}

B1. How many loans did you receive?

B2. How much was the amount of your loans and how long did they last?

\begin{tabular}{|l|l|l|l|}
\hline & AMOUNT applied for & AMOUNT disbursed & DURATION months \\
\hline 1 & & & \\
\hline 2 & & & \\
\hline 3 & & & \\
\hline 5 & & & \\
\hline
\end{tabular}

B3. Do you have difficulties in repaying the loan?
0 . No
1. Yes, some
2. Yes, a lot

B4. If yes, because of:

1. the amount of the loan

2. the interest rate

3. the expiry date of the payments

4. the failure of the new activity

5. other

B5. What did you use your loan for?

1. Begin a new job/activity/enterprise

Self Husband 1st 2nd 3rd

1.a Re-enter in the labour market after a break in the working activity

2. Improve an existing activity

3. Hire more workers

4. Upgrade your qualification in the labour market

(by education, training)

5. Trade activities

6. Other



B6. Do other members of your household participate in the activity for which you used the loan? 

0. No
1. Yes
2. Don't know

B7. Do other subjects who do not belong to your household participate in the activity for which you used the loan?
0. No
1. Yes
2. Don't know

B8. Has the participation to the programme made your consumption be more stable?
0 . No
1. Yes
2. Yes, a lot
3. Don't know

\section{SAVINGS}

C1. How much are you able to save in a month?

C2. How much were you able to save in a month before entering the programme?

C3. Did you use to keep some kind of savings before entering the program?
0 . No
1. Yes

C4. What did you use your savings for?

1. Food

2. Clothes

3. Health

4. Improving your house

5. Education

6. New agricultural activity

7. New non-agricultural activity

8. Improve an already existing activity

9. Debt repayment

10. Other

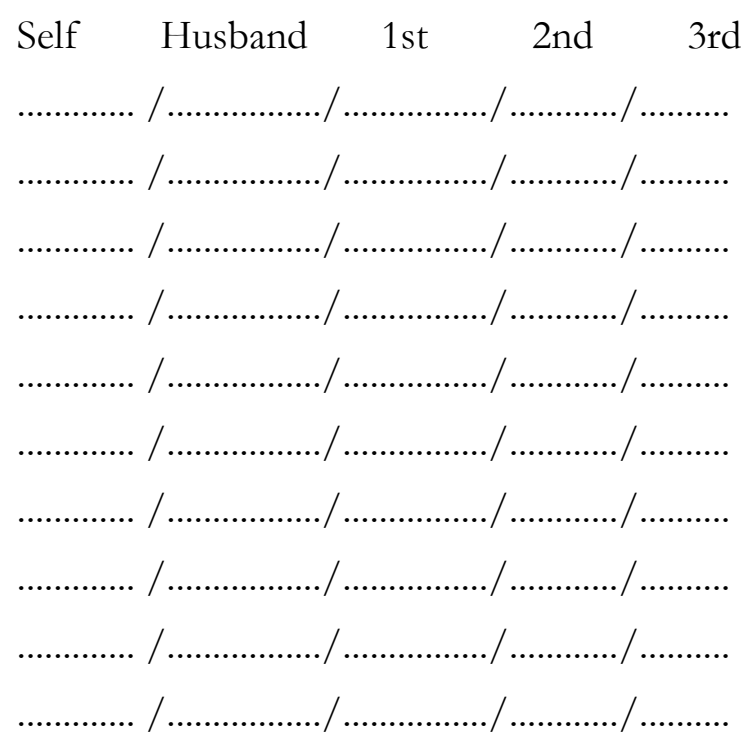

11. I didn't use them

\section{HOUSE \& FOOD DATA}

D1. Does it happen to you to have difficulties in buying or providing daily meals?:
0. No
1. Yes
2. Don't know

D2. Did it use to happen before entering the program?
0. No
1. Yes
2. Don't know

D3. Has the consumption of food since you entered the program:

1.Decreased greatly 2. Decreased 3. Stayed the same 4. Increased 5. Increased greatly

D4. Have you made any important improvement in your house since you entered the program?:
0. No
1. Yes
2. Don't know

D5. If Yes, which one: 1 . 2. 3. 


\section{EMPOWERMENT}

Since you entered the program:

E1. Your chances to go out (for working, studying, taking care of your health, having fun) have:

1.Decreased greatly 2. Decreased 3. Stayed the same 4. Increased 5. Increased greatly

E1.5 If they have increased, it was for:
1. Work
2. Fun
3. Education
4. Health

E2. Your role within you reference community has:

1.Decreased greatly 2. Decreased 3. Stayed the same 4. Increased 5. Increased greatly

E3. Your participation to the social and civil life of your community/village/country has:
1.Decreased greatly
2. Decreased 3. Stayed the same
4. Increased
5. Increased greatly

E4. Your ability in doing purchases without asking permission has:

1.Decreased greatly 2. Decreased 3. Stayed the same 4. Increased 5. Increased greatly

E5. Your participation to the decisions concerning investment within your family (for example regarding purchases of livestock, vehicles, house repairs or rental of the land) has?

1.Decreased greatly 2. Decreased 3. Stayed the same 4. Increased 5. Increased greatly

E6. Your bargaining power inside the household has:

1.Decreased greatly 2. Decreased 3. Stayed the same 4. Increased 5. Increased greatly

Thank You.

\section{THE CREDIT OFFICER}

[To fill in by the credit officer carrying out the survey]

\section{G1. Name:}

G2. Gender:

G3. Age:

G4. District:

G5. Year of involvement in the activity:

G6. Number of active clients per credit officer:

Number of individuals who are active borrowers (who currently have an outstanding loan balance with the MFI or are responsible for repaying any portion of the gross loan portfolio) ${ }^{33}$ or/ and savers with the MFI. A person with more than just one such account (i.e. with a loan and a saving account) is counted as a single client in this measure]

\section{G7. Number of women active clients per credit officer:}

[Total number of active clients who are women]

\section{G8. Average loan balance applied for/disbursed per borrower:}

\footnotetext{
${ }_{33}$ Gross Loan Porfolio: all outstanding principal for all outstanding client loans, including current, delinquent and restructured, but not loans that have been written off. It does not include interest (The Mix Market Glossary, www.mixmarket.org).
} 
[Gross loan portfolio/number of active borrowers]

G9. Average loan balance applied for/disbursed per women borrower:

[Gross loan portfolio/ number of women borrowers]

G10. Predominant area of operation:
1. Rural
2. Urban/peri-urban
3. Mixed

G11. What kind of relationship do you have with the group?
1. Professional
2. Personal 